\title{
ANNUITIZED WEALTH AND CONSUMPTION AT OLDER AGES
}

\author{
Barbara A. Butrica and Gordon B.T. Mermin* \\ CRR WP 2006-26 \\ Released: December 2006 \\ Draft Submitted: November 2006
Center for Retirement Research at Boston College 258 Hammond Street
Chestnut Hill, MA 02467
Tel: 617-552-1762 Fax: 617-552-0191
http://www.bc.edu/crr

\footnotetext{
* Barbara A. Butrica is a senior research associate at The Urban Institute. Gordon B.T. Mermin is a research associate at The Urban Institute. The research reported herein was performed pursuant to a grant from the U.S. Social Security Administration (SSA) funded as part of the Retirement Research Consortium. The findings and conclusions are solely those of the authors and do not represent the views of SSA, any agency of the Federal Government, The Urban Institute, or Boston College.

(C) 2006, by Barbara A. Butrica and Gordon B.T. Mermin. All rights reserved. Short sections of text, not to exceed two paragraphs, may be quoted without explicit permission provided that full credit, including (C) notice, is given to the source.
} 


\section{About the Center for Retirement Research}

The Center for Retirement Research at Boston College, part of a consortium that includes parallel centers at the University of Michigan and the National Bureau of Economic Research, was established in 1998 through a grant from the Social Security Administration. The Center's mission is to produce first-class research and forge a strong link between the academic community and decision makers in the public and private sectors around an issue of critical importance to the nation's future. To achieve this mission, the Center sponsors a wide variety of research projects, transmits new findings to a broad audience, trains new scholars, and broadens access to valuable data sources.

\section{Center for Retirement Research at Boston College}

258 Hammond Street

Chestnut Hill, MA 02467

phone: 617-552-1762 fax: 617-552-0191

e-mail: crr@bc.edu

www.bc.edu/crr

Affiliated Institutions:

American Enterprise Institute

The Brookings Institution

Center for Strategic and International Studies

Massachusetts Institute of Technology

Syracuse University

Urban Institute 


\begin{abstract}
The growing popularity of Individual Retirement Accounts (IRAs) and defined contribution (DC) pension plans, which generally provide benefits in the form of lump sum payments instead of annuities, is likely to affect spending patterns at older ages. People who enter retirement with little of their wealth annuitized run the risk of spending too quickly and depleting their assets before they die. Or they might spend too slowly, out of fear of running out of money, and not enjoy as comfortable a retirement as they could afford.
\end{abstract}

This study uses data from the Health and Retirement Study (HRS), including a recent supplemental expenditure survey, to examine how household expenditures among adults ages 65 and older vary by the degree of annuitization-where annuities include Social Security benefits, pensions and private annuity contracts, and Supplemental Security Income (SSI) benefits.

Results indicate that typical older married adults hold 55 percent of their retirement wealth in annuitized assets, and unmarried adults have 59 percent of their wealth annuitized. Older adults with little annuitized wealth spend more, even controlling for demographics, income, and wealth. If all defined benefit pensions (DB) were converted into unannuitized DC retirement accounts, discretionary spending could increase by as much as 3 percent for married adults and 11 percent for unmarried adults. By comparison, if Social Security was completely privatized, and retirees did not annuitize, discretionary spending could increase by as much as 22 percent for married adults and 38 percent for unmarried adults. 


\section{INTRODUCTION}

In the past, most retirees with employer pension plans received their benefits in the form of lifetime annuities, and few people entered retirement with large stocks of accumulated funds. With the growth in Individual Retirement Accounts (IRAs) and employer-sponsored defined contribution (DC) plans, increasing numbers of older Americans are now entering retirement with large account balances. Most employers do not offer annuities to their DC plan participants, and few retirees use their account balances to purchase annuities. Little is known about how quickly retirees will spend down their DC and IRA assets, or how these funds affect consumption patterns. People who have not annuitized much of their retirement wealth run the risk of spending too quickly and depleting their assets before they die. Or they might spend too slowly, out of fear of running out of money, and not enjoy as comfortable a retirement as they could afford.

This analysis uses data from a nationally representative survey of older Americans to examine the impact of annuitized wealth on household spending in retirement. We begin by comparing consumption patterns for older Americans with and without significant financial assets, including DC and IRA assets. We document differences in total expenditures, as well as differences in how retirees allocate their expenditures to such items as housing, health care, food, clothing, transportation, entertainment, gifts, and consumer durables. We then consider how the overall level and composition of expenditures vary by the degree of annuitization-where annuities include Social Security benefits, pensions and private annuity contracts, and Supplemental Security Income (SSI) benefits.

Finally, we also consider differences in consumption patterns by the type of annuitized wealth. Panis (2003) finds that the larger their share of wealth from pensions, the more satisfied people were with retirement-even controlling for income and wealth. Social Security wealth did not produce a similar effect. This result suggests that pension wealth might make people feel more secure than Social Security wealth. Along these lines, we hypothesize that the type of annuitized wealth produces differences in spending patterns. That is, older adults with annuitized pension wealth may spend their resources differently than those holding the same amount in Social Security wealth. 


\section{PREVIOUS LITERATURE}

Previous studies have examined why so few retirees purchase annuities, how workers dispose of lump sum distributions from pension plans, and consumption patterns at older ages. There has been virtually no research, however, on the consequences of annuitization on spending patterns in retirement.

A number of studies have examined why so few retirees purchase annuities. Economic theory suggests individuals with fixed resources and uncertain lifetimes should purchase insurance against the risk of outliving their resources (Yaari 1965). However, only 4 percent of workers in DC pension plans convert their account balances into annuities at separation from their employer (Hurd, Lillard, and Panis 1998; Johnson, Burman, and Kobes 2004). Mitchell et. al (1999) examine adverse selection as a reason for low rates of annuitization and find that a dollar of annuity premium only purchases about 80 to 85 cents of payout for the typical person. However, they also find the insurance value of purchasing an annuity to be of similar magnitude to this additional cost. Brown and Poterba (2000) find the potential utility gain from purchasing annuities is smaller for couples than singles and propose this as a possible explanation for low rates of annuitization as the majority of new retirees are married. Dushi and Webb (2004) find most workers enter retirement with enough annuitized wealth from Social Security and pensions that they have no need to convert any other wealth into annuities. Laitner (1997) reviews studies examining the bequest motive as an explanation for limited demand for annuities.

In addition to examining why so few retirees annuitize their assets, researchers have studied what workers do with lump-sum distributions from pension plans. In 2003, 85 percent of workers with pension plans reported their plans offered lump-sum distributions as a payout option (Purcell 2005). The data suggest workers who take lump-sum distributions often spend some of their assets when separating from their employers. Studies based on a variety of surveys and firm data consistently find that more than half (54 to 66 percent) of workers who take lumpsum distributions spend their account balances rather than rolling their assets into other employer retirement plans or IRAs (Burman, Coe, and Gale 1999; Hurd, Lee, and Panis 1998; Johnson, Burman, and Kobes 2004; Moore and Muller 2002; Purcell 2005; Verma and Lichtenstein 2006; Yakoboski 1997). 
However, statistics on the number of workers who choose not to roll-over lump sum distributions probably overstate the degree to which workers spend their nest eggs before retirement. First, the accounts that workers cash out tend to be smaller and consequently 67 to 79 percent of distributed dollars are in fact rolled over (Purcell 2005; Sabelhaus and Weiner 1999; Yakoboski 1997). Second, at least 33 percent of workers with DC plans choose not to take lump-sum distributions and leave their money in their former employer's plan (Hurd, Lee, and Panis 1998; Johnson, Burman, and Kobes 2004). Finally, workers who do not roll-over their lump-sum distributions often reinvest the money or pay down debt rather than increase consumption. Moore and Muller (2002) find that 28 percent of those workers who do not roll over their lump-sum distributions invest the money or use it to purchase a home or start a business. Studies find roll-over rates are higher for those with larger distributions, older workers, those with more education, higher income workers, whites, and women (Hurd, Lee, and Panis 1998; Moore and Muller 2002; Purcell 2005; Verma and Lichtenstein 2006).

A growing literature examines consumption patterns at older ages. These studies compare the spending patterns of older workers to younger workers (Paulin and Duly 2002), attempt to explain why consumption declines in retirement and examine whether workers expect this decline (Ameriks, Caplan, and Leahy 2001; Banks, Blundell, and Tanner 1998; Hurd and Rohwedder 2006), and compare the consumption needs of retirees to their after-tax income (Butrica, Goldwyn, and Johnson 2005). None of these studies, however, examine how the degree to which retirement wealth is annuitized affects spending in retirement. By addressing this question our study aims to better understand the implications of the shift away from traditional pensions to DC pensions and IRAs.

\section{DATA AND METHODOLOGY}

Our data come from the Health and Retirement Study (HRS), a longitudinal survey of older Americans conducted by the Survey Research Center at the University of Michigan for the National Institute on Aging. Since 1992, the HRS has been following several cohorts of older respondents and their spouses. In 2000, the survey interviewed a nationally representative sample of 19,579 Americans ages 53 and older and their spouses. The HRS collects detailed information on a wide range of subjects, including basic demographic information, detailed 
health status, and comprehensive income and asset information. It oversamples African Americans, Hispanics, and Florida residents, but includes sample weights used to adjust the estimates so that they represent the underlying national population.

The HRS administered a supplemental mail survey on household expenditures to a subset of respondents in 2001. This survey, the Consumption and Activities Mail Survey (CAMS), asked respondents to report household expenditures over the past 12 months on 32 different groups of goods and services designed to capture all household spending. Data was collected for 3,813 households. We merged the 2001 CAMS with demographic and asset information from the 2000 HRS and income information from the 2002 HRS (which collected data on income received in 2001). We also merged the 2003 CAMS with demographic and asset information from the 2002 HRS and income information from the 2004 HRS (which collected data on income received in 2003). In combination with the information collected from the core HRS questionnaires, CAMS provides an unusually rich source of data on household spending at older ages.

\section{Measuring Expenditures and Income}

To make the analysis of household spending patterns more manageable, we group expenditures into the following categories:

- housing, which includes mortgage payments, home/renter insurance premiums, property tax payments, rent, utility costs (electricity, water, heat, phone, and cable and internet services), spending on house/yard supplies, and home maintenance costs;

- health care, consisting of out-of-pocket payments on insurance premiums, drugs, health services, and medical supplies;

- food, which includes expenditures on groceries but not spending on dining outside of the home;

- transportation expenditures, which consist of payments for automobile finance charges, automobile insurance premiums, gasoline, and automobile maintenance (but which exclude any spending on public transit);

- entertainment, consisting of spending on dining out, vacations, tickets to events, and hobbies;

- gifts, which include charity and other gifts; and 
- other consumer durables, including purchases of automobiles, refrigerators, washers and dryers, dishwashers, televisions, and computers.

The analysis relates spending to household wealth and household income. Our measure of household wealth includes financial assets, housing equity, and other assets. Financial assets include IRA balances; stock and mutual fund values; bond funds; checking, savings, money market, and certificates of deposit account balances; and trusts, less unsecured debt. Housing equity is the value of home less mortgages and home loans. Other assets include the net value of other real estate; vehicles; and businesses. To household wealth we add the present discounted value (PDV) of the expected future stream of Social Security, pension, and SSI benefits from current age until age 120. The computations assume a real interest rate of 2 percent and inflation of 2.8 percent in the long run.

Household income includes payments from self-employment; wages and salaries; professional practices and trades; tips and bonuses; business income; rental income; trusts; assets, including stocks, bonds, checking accounts, certificates of deposit, and IRA withdrawals; pension benefits; annuities; SSI benefits; Social Security benefits; unemployment compensation; worker compensation; veterans' benefits; welfare benefits; food stamps; alimony support; and other income.

Our analysis is based on per capita household expenditures, income, and wealth. Considering the total values could be misleading, because each of these measures tends to increase with household size. Ignoring household size could particularly distort estimated age differences in spending, because older households tend to be smaller than younger households. Although we can estimate per capita household expenditures by simply dividing spending by the number of household members, we can only approximate per capita income and wealth. The HRS collects complete information on income and wealth only for the respondent and spouse, not for other adults who might live in the household. We set per capita income equal to household income for unmarried adults and to one-half of household income for married adults. We do the same to estimate per capita wealth. This approach assumes that the income and wealth of any other adults living in the household equals the average per capita income and wealth of the respondent and spouse.

For each measure of interest, most of our tables report the mean value between the $45^{\text {th }}$ and $55^{\text {th }}$ percentiles of the distribution. This statistic approximates the median, and better 
describes outcomes for typical people than the mean because it is less sensitive to extreme values. It is also a better statistic than the median, because the median value gives the breakdown for a single observation, which may not be representative of people in the center of the distribution. By using 10 percent of the sample, our statistic better describes the composition of expenditures and income for typical cases. For ease of exposition, we refer to this statistic as the median throughout the text, unless otherwise noted.

\section{Sample Criteria}

Our analytic sample consists of CAMS respondents ages 65 and older who report receiving either Social Security retirement or disability benefits. We restrict the sample to Social Security beneficiaries in order to focus the analysis on individuals who rely primarily on retirement benefits and assets to finance consumption rather than on earnings. In addition to respondents to the 2001 CAMS, we include respondents to the 2003 survey who were not interviewed in 2001. We only include new respondents in 2003 to avoid individuals appearing twice in our sample and consequently biasing the precision of our estimates. After dropping a few cases with missing data, our sample includes 2,053 married adults and 1,184 unmarried adults. We report results at the individual level, separately for married and unmarried adults. All expenditures, income, and wealth are expressed in 2005 dollars.

\section{RESULTS}

First we show how spending patterns relate to financial wealth for married and unmarried adults ages 65 and over. We then examine the level and composition of total retirement wealth, including Social Security and pension wealth, by demographic group. Next we show how retirement consumption varies by the degree of annuitization, as well as the type of wealth that is annuitized. We then estimate regression models of household expenditures to disentangle the impact of demographics, income, wealth, and the share of wealth annuitized. Finally, we simulate how changes in the share of wealth that is annuitized might impact spending. 


\section{Relationship between Expenditures and Financial Assets}

We begin by examining how the spending patterns of adults ages 65 and older relate to their financial wealth (table 1). Median per capita expenditures are $\$ 16,813$ for married adults and \$18,366 for unmarried adults. Similar to Butrica, Goldwyn, and Johnson (2004), we find housing and health care to be the largest spending categories, comprising 47 percent of all spending for typical married adults and 57 percent of all spending for typical unmarried adults. Basic needs (housing, health care, food, and clothing) comprise almost two-thirds of expenditures for typical married respondents and almost three-quarters of expenditures for typical unmarried respondents.

The majority of older adults, 89 percent of married and 79 percent of unmarried, report positive financial wealth, which could easily be annuitized to support consumption in retirement. About one-third of both married and unmarried adults have some financial assets but no more than $\$ 25,000$ per person. With $\$ 25,000$, a 65-year-old adult could purchase a single life annuity that would provide $\$ 180$ per month for the rest of his or her life. ${ }^{1}$ One-third of married and onequarter of unmarried adults have financial assets of more than $\$ 100,000$. With $\$ 100,000$, this individual could purchase an annuity that would provide $\$ 720$ per month. To put this in context, the average per capita household Social Security benefit for this sample is about $\$ 842$ per month.

Those with greater financial wealth spend more than those with less wealth, and a greater share of their spending is for discretionary purposes. Median retirees with more than $\$ 100,000$ in financial assets have per capita expenditures that are nearly twice as high as for those without assets. Among median married adults, those with more than $\$ 100,000$ in assets spend about equal amounts on basic expenditures and discretionary expenditures, such as transportation, entertainment, gifts, and other consumer durables. In contrast, those with zero or negative financial assets spend 76 percent of their budgets on basic needs and 24 percent on discretionary items. The difference is most striking for housing, which constitutes 27 percent of spending for the highest asset category as opposed to 47 percent for the lowest asset category, and entertainment and gifts, which constitute 32 percent of spending for the highest asset category while only 8 percent for the lowest category. Differences in the level and composition of expenditures across financial asset categories is similar, though less dramatic, for unmarried

\footnotetext{
${ }^{1}$ Based on Group Annuity Mortality 1971 (GAM71) unisex mortality table and an interest rate of 4.125 percent.
} 
adults. For example, median unmarried individuals with more than a $\$ 100,000$ in assets allocate 63 percent of their spending to basic expenditures. In contrast, those without any assets allocate 75 percent of their budgets to basic items.

\section{Expenditures and the Level and Composition of Household Wealth}

It is clear from the data that a large number of older adults have significant financial assets that can be used to support consumption in retirement. However, most older adults have other sources of wealth, including housing equity, vehicles and businesses, and future Social Security, pension, and SSI benefits. Table 2 shows mean per capita expenditures and wealth for

married adults with household expenditures in the $45^{\text {th }}$ to $55^{\text {th }}$ percentiles. Average total wealth is $\$ 377,365$ of which less than a fifth comes from financial assets. Social Security is the largest source of wealth, comprising 41 percent of the total on average. Another 26 percent of wealth is from housing, vehicles, and businesses, and 14 percent is from pension annuities. Married adults with median expenditures have no wealth from SSI. The last column of table 2 shows the average share of wealth from annuities (Social Security, pensions, and SSI). As Dushi and Webb (2004) point out, the share of wealth annuitized is large. We find that it is 55 percent for the typical married adult.

Expenditures and wealth vary by demographic and economic characteristics in expected ways. They are highest for those who are non-Hispanic white, college educated, in excellent or very good health, homeowners with mortgages, and in the top third of income. In contrast, expenditures and wealth are lowest for those who are minority, without a high-school degree, in fair or poor health, renters, and in the bottom third of income. Different from those with high expenditures and wealth, older adults with low expenditures and wealth hold the bulk of their wealth in Social Security and relatively little of their wealth in pension annuities and financial assets. Social Security's progressive payment formula provides lower-income workers with a higher benefit relative to lifetime earnings. In contrast, pension benefits depend more directly on earnings than Social Security and higher-income workers are more likely to have pension coverage than lower-income workers.

As a result, Social Security comprises 73 percent of wealth for non-Hispanic blacks, but only 42 percent for non-Hispanic whites. Pension annuities make up 6 percent of wealth for 
non-Hispanic blacks, but 15 percent of wealth for non-Hispanic whites. Similarly, financial assets comprise only 2 percent of wealth for non-Hispanic blacks, but 17 percent for nonHispanic whites. Consequently, low socio-economic groups tend to have higher shares of their wealth annuitized. For example, 68 percent of wealth comes from annuity payments for individuals in the bottom third of wealth, compared with only 41 percent for those in the top third.

Table 3 shows mean expenditures and wealth for unmarried adults with household expenditures in the $45^{\text {th }}$ to $55^{\text {th }}$ percentiles. Compared with married adults, unmarried adults have lower total wealth and hold a larger share of this wealth in Social Security and SSI, and a smaller share in pension annuities and financial assets. Taking Social Security, pension annuities, and SSI together, a higher share of their wealth is annuitized. Average total wealth is \$330,084 with 48 percent coming from Social Security, 26 percent from housing and other, 14 percent from financial assets, 10 percent from pensions, and one percent from SSI. On average, annuitized wealth comprises 59 percent of total wealth.

Expenditures, wealth, and the share of wealth annuitized differ by personal and economic characteristics for unmarried adults in similar ways as for married adults. High socio-economic groups have high expenditures and wealth and low shares of wealth annuitized, while low socioeconomic groups have low expenditures and wealth and high shares of wealth annuitized. In some cases, demographic group differences are more extreme among unmarried adults than married adults. For example, Social Security comprises 91 percent of wealth for non-Hispanic blacks and 48 percent for non-Hispanic whites. Additionally, financial assets are a negative (debt exceeds assets) share of wealth for non-Hispanic blacks and a 16 percent share of wealth for non-Hispanic whites. Tables A1 and A2 in the Appendix show the dollar value of each of the components of wealth described above.

\section{Spending Patterns by the Degree of Annuitization}

Table 4 describes how the level and composition of median per capita expenditures varies with the share of wealth annuitized. About 15 percent of older adults hold less than 25 percent of wealth in annuities, an additional 30 percent hold 25 to 50 percent of wealth in annuities, and another 55 percent hold 50 to 100 percent in annuities. Married adults are less likely (20 
percent) than their unmarried counterparts (30 percent) to have more than 75 percent of their wealth annuitized.

As suggested in tables 2 and 3, expenditures decline as the degree of annuitization increases. For both married and unmarried adults, median expenditures decline from about $\$ 27,000$ for those with less than 25 percent of wealth annuitized to close to $\$ 14,000$ for those with more than 75 percent of wealth annuitized. Compared with unmarried adults; however, married adults' expenditures decline less uniformly as their degree of annuitization increases. Married older adults with 25 to 50 percent of wealth in annuities spend 36 percent less than those holding less than 25 percent of wealth in annuities. There is virtually no difference in expenditures between the group holding 50 to 75 percent of wealth in annuities and the group holding 25 to 50 percent of wealth in annuities. However, married adults holding 75 to 100 percent of wealth in annuities spend 21 percent less than those holding 50 to 75 percent of wealth in annuities.

Budget shares for basic expenditures increase with the share of wealth annuitized. Married individuals holding less than 25 percent of wealth in annuities spend 51 percent of their budgets on basic items, while those who maintain more than 75 percent of their wealth in annuities allocate 70 percent of their budgets to basic goods. While spending patterns are similar for unmarried individuals, their budget shares for basic expenditures are larger.

These results are due at least in part to the negative correlation between expenditures, income, and wealth, and the degree of annuitization (observed in tables 2 and 3). That is, low socio-economic groups have low expenditures and wealth and high shares of wealth annuitized. However, we find expenditures are lower for adults with more of their wealth annuitized, regardless of income (table 5). The regression analysis will further disentangle the impact of income, wealth, and the share of wealth annuitized on household spending.

Next we examine whether different sources of annuitized wealth affect spending differently (table 6). First, we consider Social Security wealth. Social Security comprises more than one-half of total wealth for 29 percent of married adults and 40 percent of unmarried adults. As is in table 4, expenditures decline and the proportion of expenditures going to basic spending increase as the share of wealth coming from Social Security increases. Median expenditures are $\$ 24,445$ for married adults and \$26,574 for unmarried adults with less than 25 percent of wealth from Social Security, but about $\$ 11,500$ for married and unmarried adults with more than 75 
percent of wealth from Social Security. For married adults, basic spending is 53 percent of total expenditures for median married adults with less than 25 percent of wealth coming from Social Security and 61 percent for those with more than 75 percent of wealth from Social Security.

In many ways, the trend is different for pension wealth. First, a significant share of the population (40 percent of married and 54 percent of unmarried adults) has no annuitized pension wealth at all. Second, expenditures increase, not decrease, as the share of wealth from pensions increases. For instance, married adults with less than 25 percent of wealth from pensions spend $\$ 16,674$ while those with more than 50 percent from pensions spend $\$ 19,380$. Third, there is not a positive correlation between the share of wealth from pensions and the share of basic expenditures. The share of basic spending is about the same for those with less than 25 percent and more than 50 percent of wealth from annuitized pensions, and is lower for those in the 25 to 50 percent range. The difference observed is due at least in part to many low-wage workers arriving at retirement with little wealth other than Social Security. Consequently, wealth is negatively correlated with Social Security and positively correlated with pensions. Our regression analysis will test whether Social Security and pension wealth have different impacts on expenditures holding income and wealth constant.

\section{Modeling Household Spending and the Share of Wealth Annuitized}

Next we estimate multivariate models of household consumption on the share of wealth annuitized. Because expenditures tend to be highly skewed, we estimate median regressions. We control for personal characteristics, income, and wealth in order to separate their influence on household spending from that of the share of wealth held in annuities. The coefficient on the share of wealth annuitized indicates whether, all things equal, retirees with large IRA or DC account balances spend differently than those holding most of their wealth in Social Security and pensions.

Table 7 reports the means for the variables in the regressions and whether differences between married and unmarried adults are statistically significant. As already discussed, per capita expenditures are significantly lower for married adults than for unmarried adults. The married adults in our sample are slightly younger than the unmarried adults. They are also more likely than unmarried adults to be non-Hispanic white, college educated, male, in excellent or 
very good health, and homeowners. They also have more per capita income and wealth. Finally, older adults who are married have significantly less annuitized wealth than those who are not married (52.9 and 58.4 percent, respectively). For married adults, this wealth is less likely to come from Social Security and more likely to come from pension annuities.

For married adults, the regression results confirm that overall household spending is negatively correlated with the share of wealth from annuitized assets (table 8). The coefficients on the main term, squared term, and cubed term are jointly significant which suggests that the relationship is nonlinear. Holding all other variables at their means, figure 1 graphically depicts the relationship between spending and the share of wealth annuitized. Predicted household spending decreases with each percentage point increase in the share of wealth annuitized up to about 42 percent. Thirty-four percent of married adults fall into this group. Then household spending increases slightly with each percentage point increase in the share of wealth annuitized up to the point at which about 71 percent of wealth is annuitized. About 40 percent of married adults have between 42 and 71 percent of their wealth annuitized. Beyond 71 percent, household spending again decreases with each percentage point increase in the share of wealth annuitized. Twenty-five percent of married adults fall into this group.

When we separate out the type of wealth that is annuitized, we find that the share of wealth held in pension annuities has a much larger impact on expenditures than the share held in Social Security. All pension coefficients are jointly significant suggesting that this relationship is also nonlinear. In contrast, the coefficients on the share of wealth from Social Security are all insignificant, which suggests that for married adults it has no impact on household spending.

We also examine whether the share of wealth annuitized impacts basic and discretionary expenditures differently. For example, one could imagine that retirees with a lot of their wealth annuitized might feel more comfortable dining out, taking vacations, and buying gifts for family and friends because they have a steady and endless source of income. The share of wealth from Social Security has a significant, but small, negative impact on basic expenditures, while the share of wealth from pension annuities has no significant impact on basic expenditures. In contrast, the share of wealth from Social Security has no significant impact on discretionary expenditures, while the share of wealth from pension annuities has a significant and negative impact on discretionary expenditures. 
Other coefficient estimates for the models are generally as expected. Household spending varies directly with income and wealth. Workers have significantly higher basic expenditures than those who do not work. Renters and homeowners with mortgages spend more on basic goods (such as housing) than homeowners without mortgages. Those in fair or poor health spend significantly less on discretionary items than those in good health. Also, retirees living in rural areas spend less than those living in suburban areas. Spending varies by Hispanicity and education even after controlling for income and wealth. Hispanics spend less than non-Hispanic whites on both basic and discretionary items. College graduates have higher expenditures, particularly discretionary outlays, and those without high school degrees have lower expenditures than high school graduates.

We estimated similar models for unmarried adults and found the relationship between household spending and the share of wealth annuitized to be linear (table 9). For this reason, we excluded the squared and cubed terms from the regressions. Overall, the impact of annuitized wealth on expenditures is much stronger for unmarried adults than for married adults. An increase of 1 percentage point in the share of wealth annuitized reduces household spending by .37 percent. In contrast to married adults, we find that Social Security has a much larger impact on expenditures than do pensions. A 1 percentage point increase in the share of wealth from Social Security reduces household spending by .49 percent. Though these effects are similar for both basic and discretionary expenditures, the impact is much stronger for discretionary spending. That is, when the share of wealth annuitized increases by 1 percentage point, discretionary spending declines by .78 percent. In particular, when the share of wealth from Social Security increases by 1 percentage point, discretionary spending declines by .96 percent.

These results show that, even controlling for income, wealth, and other personal characteristics, retirees with little annuitized wealth spend more than those with a lot of annuitized wealth. To ensure that our results are not driven by lower-income workers who arrive at retirement with little wealth other than Social Security, we performed sensitivity tests by running the same regressions on those with wealth above the $66^{\text {th }}$ percentile. For both married and unmarried adults, the general results remain unchanged. 


\section{The Impact of Changes in the Share of Wealth Annuitized on Spending}

To assist in interpreting the key coefficients in the regressions, table 10 describes the impact on household expenditures of decreasing the share of wealth annuitized by 10 percentage points. Except for pensions, the effects are smaller for married than for unmarried adults. Decreasing the share of wealth annuitized by 10 percentage points increases the overall spending of typical married adults by 3 percent. This small impact is driven entirely by pensions. That is, holding the share of wealth from Social Security constant, decreasing the share of wealth from annuitized pensions increases overall household spending by 6 percent. As the regression results suggest, discretionary spending is much more responsive to the degree of annuitization than is basic spending.

Again, the effects are much stronger for unmarried adults. Decreasing the share of wealth annuitized by 10 percentage points increases overall spending by 4 percent, basic spending by 3 percent, and discretionary spending by 8 percent. Different from married adults, this result is driven entirely by Social Security. Holding the share of wealth from pension annuities constant, a decrease in the share of wealth from Social Security increases overall household spending by 5 percent. As with married adults, the share of wealth annuitized has a much larger impact on unmarried adults' discretionary expenditures than basic expenditures.

Because the relationship between household spending and the share of wealth annuitized is nonlinear for married adults, a change in the share annuitized does not impact expenditures equally for everyone. As depicted in figure 2, a 10 percentage point decline in the share of wealth annuitized results in a 9 percent increase in expenditures for those with 42 percent or less of their wealth annuitized, a 1 percent decrease in expenditures for those with between 42 and 71 percent of their wealth annuitized, and a 2 percent increase in expenditures for those with 71 percent or more of their wealth annuitized.

Next, we simulate the possible impact of pension trends and Social Security personal retirement accounts (PRA) on household spending (table 11). Each of these simulations creates more potentially unannuitized wealth. First, we simulate the impact of the trend away from DB pensions continuing until all pension wealth comes from DC pensions. For married adults, the median share of wealth annuitized decreases from 55 to 41 percent resulting in a 2 percent increase in total household spending. For unmarried adults, the median share of wealth 
annuitized decreases from 59 to 49 percent. This results in a 4 percent increase in basic expenditures and an 11 percent increase in discretionary expenditures.

Next, we examine how household spending would differ if Social Security established PRAs. Under most reform proposals, Social Security benefits would be reduced by the account contributions accumulated in the PRA. For example, one recent progressive price indexing proposal would result in about 25 percent of Social Security benefits coming from private accounts in 2055 for medium single-earner couples and as much as 50 percent for single-earner couples receiving maximum benefits. ${ }^{2}$ If 25 percent of Social Security benefits were diverted to an unannuitized PRA, our simulations suggest that the share of wealth annuitized would decline to 45 percent for married adults and 47 percent for unmarried adults. This would increase total spending by 1 percent for married adults and 4 percent for unmarried adults, and discretionary spending by 2 percent for married adults and 8 percent for unmarried adults. If 50 percent of Social Security benefits were diverted to a PRA, discretionary spending would increase by 4 percent for married adults and 17 percent for unmarried adults.

One feature of many PRA proposals is that over time account balances comprise an increasingly larger share of Social Security benefits. We simulate this by assuming that the total amount of Social Security benefits is captured in an unannuitized PRA. For the typical married adult, we find that the share of wealth annuitized declines to only 14 percent and that discretionary expenditures increase by 22 percent. For the typical unmarried adult, the share of wealth annuitized declines to only 11 percent and discretionary expenditures increase by 38 percent.

\section{CONCLUSIONS}

The growing popularity of IRAs and DC pension plans coupled with the limited demand for annuities suggests that many Americans will retire with large stocks of accumulated wealth. However, little is known about how quickly retirees will spend down their IRA and DC assets, or how these funds affect consumption patterns. People who have not annuitized much of their retirement wealth run the risk of spending too quickly and depleting their assets before they die.

\footnotetext{
${ }^{2}$ Authors' computations based estimates reported in tables B1 and B2 from Goss (2005). Workers who earn at least the maximum amount covered by Social Security in all years would receive maximum benefits.
} 
Or they might spend too slowly, out of fear of running out of money, and not enjoy as comfortable a retirement as they could afford.

We find no evidence that older adults are afraid to draw down their assets to finance consumption. That is, our analysis of data from a nationally representative survey of older Americans shows that retirees with little annuitized wealth spend more than other retirees-even after controlling for income, wealth, and other personal characteristics. Annuitized wealth from Social Security, pensions and private annuity contracts, and SSI represents 55 percent of total wealth for typical married adults and 59 percent of total wealth for unmarried adults. When the share of wealth annuitized declines by 10 percentage points, household spending increases by 3 percent for married adults and 4 percent for unmarried adults. Pension wealth has a bigger effect on the expenditures of married adults, while Social Security wealth has a bigger effect on the expenditures of unmarried adults.

Discretionary spending on items such as transportation, entertainment, gifts, and other consumer durables is more responsive to the degree of annuitization than is basic spending on items such as housing, health care, food, and clothing. For married adults, a 10 percentage point decline in the share of wealth annuitized increases basic spending by 2 percent and discretionary spending by 3 percent. For unmarried adults, basic spending increases by 3 percent, but discretionary spending increases by 8 percent.

As employers abandon traditional DB pensions for DC pensions, and as policymakers consider reforms to privatize the Social Security system, it is important to understand how all of this potentially unannuitized wealth might impact well-being in retirement. According to our simulations, these developments may promote even further spending of retirement resources. The trend away from DB pensions toward DC pensions could increase discretionary spending by as much as 3 percent for married adults and 11 percent for unmarried adults. By comparison, if Social Security was completely privatized, and retirees did not annuitize, discretionary spending could increase by as much as 22 percent for married adults and 38 percent for unmarried adults.

Although we find that older adults with little annuitized wealth spend more than others, it is still unclear how this impacts their retirement security. On the one hand, they are at greater risk of outliving their assets and ending up poor at older ages. On the other hand, seniors with large account balances may be better able to maintain their standards of living when they experience unexpected consumption needs due to health shocks, for example, because can draw 
down their assets as necessary. Only when data become available for examining consumption paths and the spend-down of assets over time will researchers be able to fully evaluate whether retirees with less of their wealth annuitized are ultimately worse off than others. 


\section{REFERENCES}

Ameriks, John, Andrew Caplin, John Leahy, 2002. "Retirement Consumption: Insight From a Survey.” NBER Working Paper 88735. Cambridge, MA: National Bureau of Economic Research.

Banks, James, Richard Blundell, Sarah Turner, 1998. “Is There a Retirement-Savings Puzzle?” The American Economic Review, Vol. 88, No. 4: 769-788.

Brown, Jeffrey R., and James M. Poterba. 2000. “Joint Life Annuities and Annuity Demand by Married Couples.” The Journal of Risk and Insurance, Vol. 67, No. 4: 527-553.

Butrica, Barbara A., Joshua H. Goldwyn, and Richard W. Johnson, 2005. "Understanding Expenditure Patterns in Retirement.” CRR Working Paper No. 2005-03. Chestnut Hill, MA: Center for Retirement Research at Boston College.

Burman, Leonard E., Norma B. Coe, and William G. Gale. 1999. “Lump Sum Distributions from Pension Plans: Recent Evidence and Issues for Policy and Research.” National Tax Journal, Vol. LII, No. 3: 553-562.

Dushi, Irena and Anthony Webb. 2004. “Annuitization: Keeping Your Options Open .” CRR WP 2004-04. Chestnut Hill, MA: Center for Retirement Research at Boston College.

Goss, Stephen C. 2005. “Memorandum: Estimated Financial Effects of a Comprehensive Social Security Reform Proposal Including Progressive Price Indexing.” Baltimore, Maryland: Social Security Administration Office of the Chief Actuary.

Hurd, Michael, Lee Lillard, Constantijn Panis, 1998. “An Analysis of the Choice to Cash Out Pension Rights at Job Change or Retirement.” Santa Monica, CA: RAND.

Hurd, Michael, Susann Rohwedder, 2006. "Some Answers to the Retirement-Consumption Puzzle.” Santa Monica, CA: RAND.

Johnson, Richard W., Leonard E. Burman, and Deborah I. Kobes. 2004. "Wealth annuitized at Older Ages: Evidence from the Health and Retirement Study.” Washington, DC: The Urban Institute.

Mitchell, Olivia S., James M. Poterba, Mark J. Warshawsky, and Jeffrey R. Brown. 1999. “New Evidence on the Money's Worth of Individual Annuities.” The American Economic Review, Vol. 89, No. 5: 1299-1318.

Moore, James F., and Olivia S. Mitchell. 2000. "Projected Retirement Wealth and Savings Adequacy in the Health and Retirement Study.” In Olivia S. Mitchell, P. Brett Hammond, and Anna M. Rappaport, eds., Forecasting Retirement Needs and Retirement Wealth (pp. 68-94). Philadelphia, PA: Pension Research Council and the University of Pennsylvania Press. 
Moore, James H. Jr., and Leslie A. Muller. 2002. “An Analysis of Lump-Sum Pension Distribution Recipients.” Monthly Labor Review, May, pp. 29-45.

Panis, Constantijn W. 2004. “Annuities and Retirement Well-Being.” In Olivia S. Mitchell, Stephen P. Utkus, eds., Pension Design and Structure: New Lessons from Behavioral Finance (pp. 259-274). Oxford: Oxford University Press.

Paulin, Geoffrey D. and Abby L. Duly. 2002. "Planning Ahead: Consumer Expenditures in Retirement.” Monthly Labor Review, July, pp. 38-58.

Verma, Satyendra and Jules Lichtenstein, 2006. "Pension Lump-Sum Distributions: Do Boomers Take Them or Save Them?” Data Digest. Washington, DC: AARP Public Policy Institute.

Yaari, Menahem E. 1965. "Uncertain Lifetime, Life Insurance, and the Theory of the Consumer.” Review of Economic Studies, 32(April):137-150. 
Figure 1. Predicted Household Expenditures by Share of Annuitized Wealth Married Adults 65+ Who Collect Either SS or SSDI

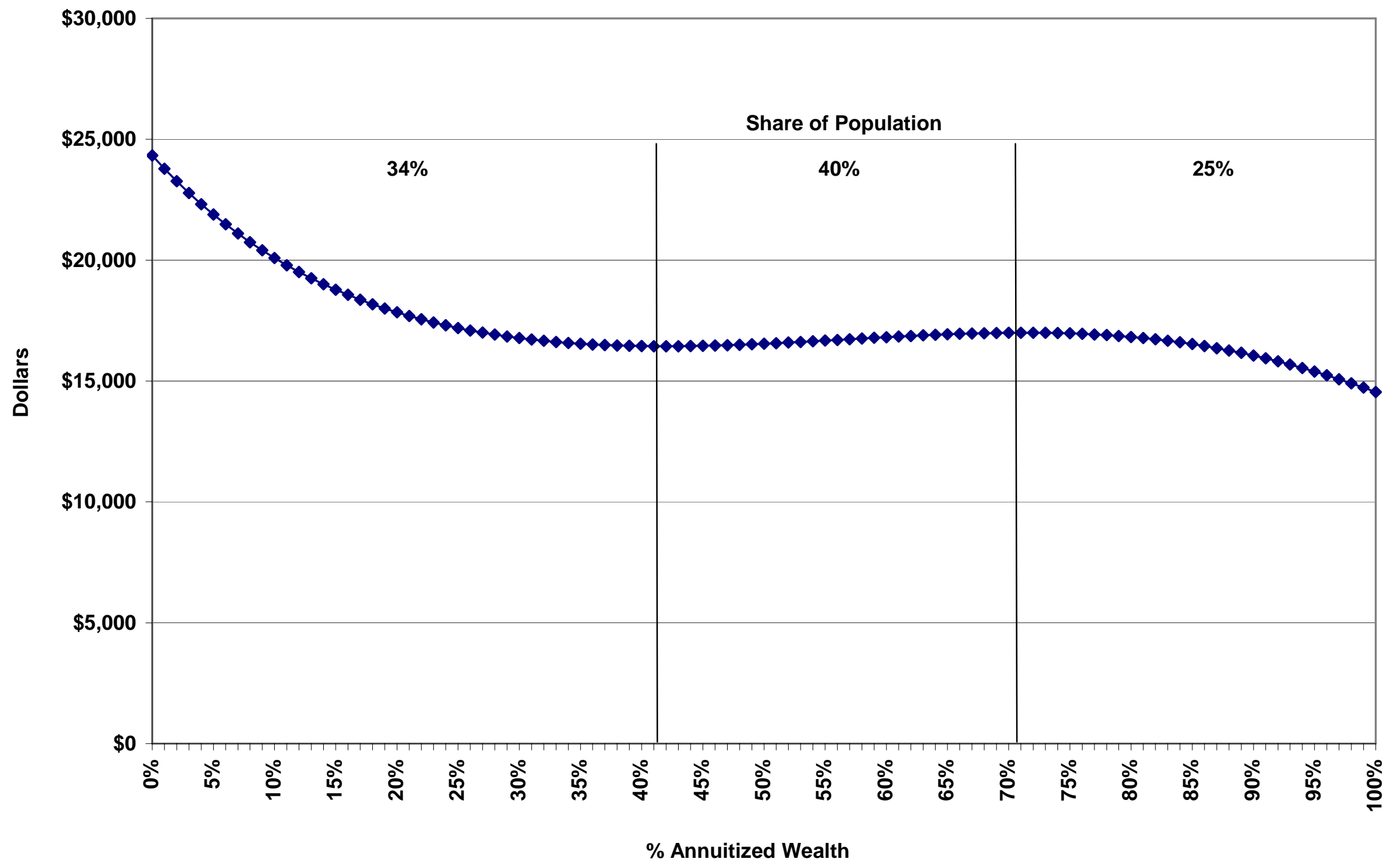


Figure 2. Impact of Decreasing the Share of Annuitized Wealth by 10 Percentage Points on Household Expenditures

Married Adults 65+ Who Collect Either SS or SSDI

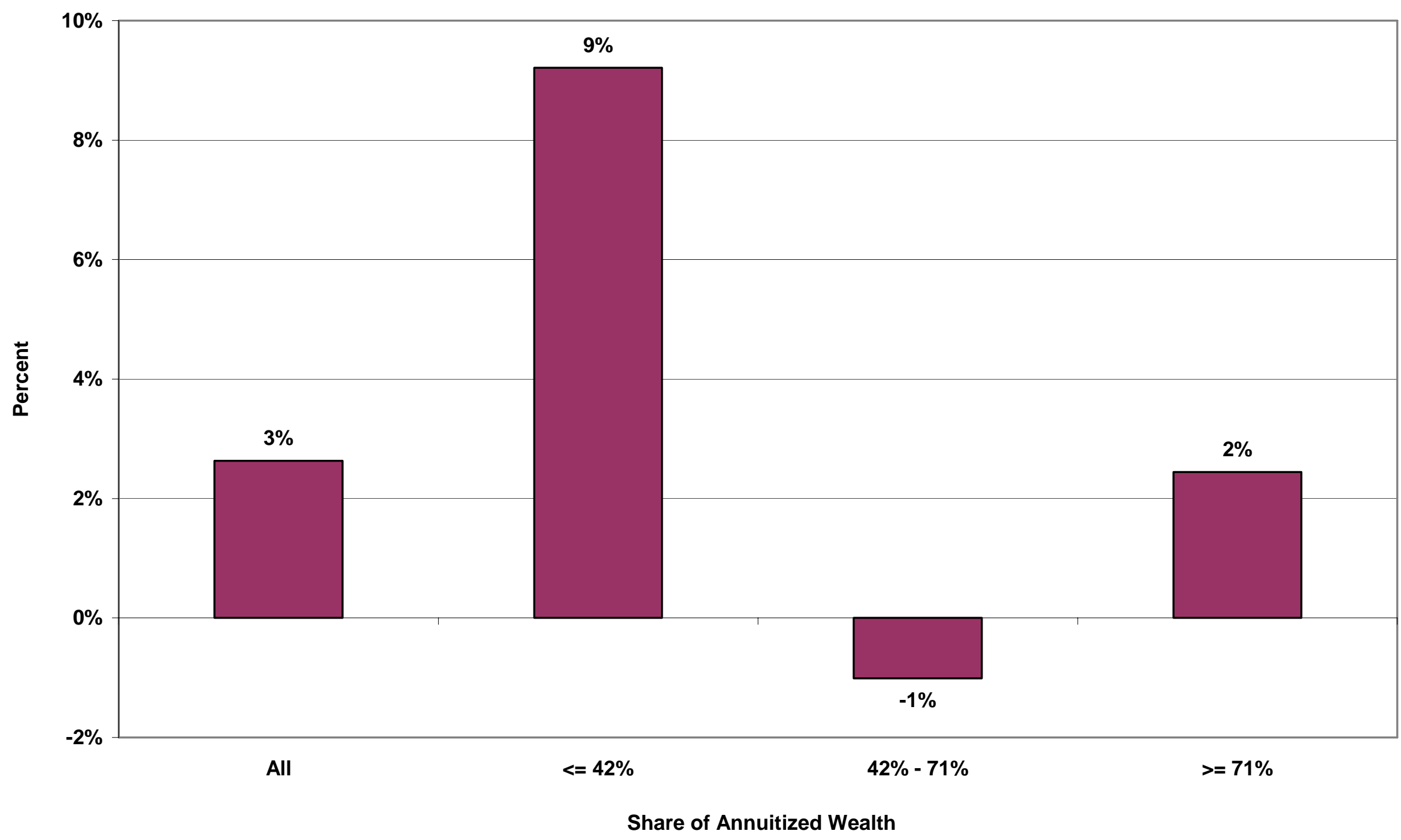


Table 1. Median Per Capita Household Expenditures by the Distribution of Financial Wealth Adults Ages 65+ Who Collect Either SS or SSDI

\begin{tabular}{|c|c|c|c|c|c|}
\hline & \multirow[b]{2}{*}{ All } & \multicolumn{4}{|c|}{ Financial Assets } \\
\hline & & $\begin{array}{c}\text { Negative or } \\
\$ 0 \\
\end{array}$ & $\begin{array}{c}\$ 1- \\
\$ 25,000 \\
\end{array}$ & $\begin{array}{l}\$ 25,001- \\
\$ 100,000 \\
\end{array}$ & $\begin{array}{c}\text { Greater than } \\
\$ 100,000\end{array}$ \\
\hline \multicolumn{6}{|l|}{ A. Married } \\
\hline Share of Observations & $100 \%$ & $11 \%$ & $30 \%$ & $25 \%$ & $34 \%$ \\
\hline Median Expenditures & $\$ 16,813$ & $\$ 13,047$ & $\$ 13,958$ & $\$ 16,259$ & $\$ 24,207$ \\
\hline \multicolumn{6}{|c|}{ Median Share of Expenditures } \\
\hline Housing & $28 \%$ & $47 \%$ & $31 \%$ & $26 \%$ & $27 \%$ \\
\hline Health Care & $19 \%$ & $15 \%$ & $20 \%$ & $22 \%$ & $10 \%$ \\
\hline Food & $13 \%$ & $12 \%$ & $16 \%$ & $14 \%$ & $9 \%$ \\
\hline Clothing & $3 \%$ & $2 \%$ & $2 \%$ & $2 \%$ & $2 \%$ \\
\hline Transportation & $13 \%$ & $12 \%$ & $14 \%$ & $11 \%$ & $11 \%$ \\
\hline Entertainment & $11 \%$ & $5 \%$ & $9 \%$ & $11 \%$ & $18 \%$ \\
\hline Gifts & $9 \%$ & $3 \%$ & $6 \%$ & $12 \%$ & $14 \%$ \\
\hline Other & $3 \%$ & $4 \%$ & $1 \%$ & $3 \%$ & $8 \%$ \\
\hline Basic & $63 \%$ & $76 \%$ & $69 \%$ & $64 \%$ & $49 \%$ \\
\hline Discretionary & $37 \%$ & $24 \%$ & $31 \%$ & $36 \%$ & $51 \%$ \\
\hline \multicolumn{6}{|l|}{ B. Unmarried } \\
\hline Share of Observations & $100 \%$ & $21 \%$ & $33 \%$ & $20 \%$ & $26 \%$ \\
\hline Median Expenditures & $\$ 18,366$ & $\$ 14,157$ & $\$ 14,836$ & $\$ 19,856$ & $\$ 27,216$ \\
\hline \multicolumn{6}{|c|}{ Median Share of Expenditures } \\
\hline Housing & $41 \%$ & $41 \%$ & $40 \%$ & $33 \%$ & $39 \%$ \\
\hline Health Care & $16 \%$ & $13 \%$ & $18 \%$ & $14 \%$ & $14 \%$ \\
\hline Food & $14 \%$ & $18 \%$ & $16 \%$ & $11 \%$ & $8 \%$ \\
\hline Clothing & $3 \%$ & $3 \%$ & $3 \%$ & $4 \%$ & $3 \%$ \\
\hline Transportation & $10 \%$ & $12 \%$ & $13 \%$ & $9 \%$ & $11 \%$ \\
\hline Entertainment & $7 \%$ & $5 \%$ & $5 \%$ & $12 \%$ & $10 \%$ \\
\hline Gifts & $7 \%$ & $4 \%$ & $5 \%$ & $12 \%$ & $12 \%$ \\
\hline Other & $3 \%$ & $3 \%$ & $0 \%$ & $5 \%$ & $5 \%$ \\
\hline Basic & $73 \%$ & $75 \%$ & $76 \%$ & $61 \%$ & $63 \%$ \\
\hline Discretionary & $27 \%$ & $25 \%$ & $24 \%$ & $39 \%$ & $37 \%$ \\
\hline
\end{tabular}

Note: The universe is unique respondents in the 2001/2003 CAMS ages 65 and older in the 2000/2002 HRS who report receiving either Social Security (SS) or Social Security Disability Insurance (SSDI) in the 2002/2004 HRS. Estimates are based on a sample of 2,053 married and 1,184 unmarried adults. Basic expenditures include housing, health care, food, and clothing. Discretionary expenditures include transportation, entertainment, gifts, and other consumer durables. The median value is measured as the mean value between the 45th and 55th percentiles of the distribution. All expenditures are expressed in 2005 dollars.

Source: Authors' estimates from the Health and Retirement Study. 
Table 2. Mean Per Capita Household Expenditures and Wealth Among Adults with Median Expenditures Married Adults Ages 65+ Who Collect Either SS or SSDI

\begin{tabular}{|c|c|c|c|c|c|c|c|c|}
\hline & $\begin{array}{c}\text { Total } \\
\text { Expenses }\end{array}$ & $\begin{array}{c}\text { Total } \\
\text { Wealth }\end{array}$ & $\begin{array}{c}\text { Financial } \\
\text { Assets }\end{array}$ & $\begin{array}{c}\text { Housingl } \\
\text { Other }\end{array}$ & $\begin{array}{c}\text { Social } \\
\text { Security } \\
(1)\end{array}$ & $\begin{array}{c}\text { Pensions } \\
\text { IAnnuities } \\
\text { (2) }\end{array}$ & $\begin{array}{l}\text { SSI } \\
(3)\end{array}$ & $\begin{array}{l}\text { Annuitized } \\
\text { Wealth } \\
(1)+(2)+(3)\end{array}$ \\
\hline All & $\$ 16,813$ & $\$ 377,365$ & $19 \%$ & $26 \%$ & $41 \%$ & $14 \%$ & $0 \%$ & $55 \%$ \\
\hline \multicolumn{9}{|l|}{ Age } \\
\hline $65-69$ & 17,412 & 412,137 & 16 & 23 & 43 & 17 & 0 & 60 \\
\hline 70-79 & 16,763 & 319,282 & 17 & 28 & 41 & 14 & 0 & 55 \\
\hline$>=80$ & 14,779 & 391,381 & 30 & 33 & 30 & 7 & 0 & 37 \\
\hline \multicolumn{9}{|l|}{ Race } \\
\hline Non-Hispanic White & 17,277 & 363,009 & 17 & 27 & 42 & 15 & 0 & 56 \\
\hline Non-Hispanic Black & 13,936 & 139,188 & 2 & 20 & 73 & 6 & 0 & 78 \\
\hline Hispanic & 8,704 & 193,989 & 1 & 39 & 49 & 11 & 0 & 60 \\
\hline \multicolumn{9}{|l|}{ Education } \\
\hline Less than high school & 12,049 & 271,738 & 12 & 30 & 52 & 6 & 0 & 59 \\
\hline GED or high school graduate & 15,544 & 346,606 & 18 & 27 & 44 & 12 & 0 & 56 \\
\hline Some college or more & 22,030 & 545,944 & 24 & 25 & 33 & 18 & 0 & 51 \\
\hline \multicolumn{9}{|l|}{ Sex } \\
\hline Male & 17,211 & 379,120 & 17 & 26 & 43 & 14 & 0 & 57 \\
\hline Female & 16,316 & 374,031 & 18 & 29 & 38 & 14 & 0 & 52 \\
\hline \multicolumn{9}{|l|}{ Self-Reported Health } \\
\hline Excellent / Very Good & 19,094 & 423,471 & 20 & 26 & 39 & 16 & 0 & 55 \\
\hline Good & 16,253 & 342,307 & 17 & 29 & 40 & 14 & 0 & 54 \\
\hline Fair / Poor & 14,021 & 278,715 & 16 & 24 & 50 & 10 & 0 & 60 \\
\hline \multicolumn{9}{|l|}{ Employment Status } \\
\hline Working & 19,620 & 308,407 & 10 & 25 & 55 & 9 & 0 & 65 \\
\hline Not Working & 16,500 & 385,870 & 20 & 25 & 40 & 15 & 0 & 55 \\
\hline \multicolumn{9}{|l|}{ Housing Tenure } \\
\hline Owner / No Mortgage & 15,092 & 429,440 & 22 & 32 & 35 & 11 & 0 & 46 \\
\hline Owner / Mortgage & 21,712 & 418,497 & 13 & 28 & 44 & 15 & 0 & 59 \\
\hline Renter & 16,675 & 161,647 & 7 & 3 & 79 & 10 & 1 & 90 \\
\hline \multicolumn{9}{|l|}{ Urban/Rural } \\
\hline Urban & 17,973 & 331,651 & 14 & 24 & 45 & 16 & 0 & 62 \\
\hline Suburban & 17,646 & 411,903 & 24 & 24 & 40 & 12 & 0 & 52 \\
\hline Rural & 14,607 & 443,163 & 12 & 38 & 40 & 9 & 0 & 49 \\
\hline \multicolumn{9}{|l|}{ Income } \\
\hline Bottom 1/3 & 12,613 & 236,178 & 12 & 26 & 56 & 6 & 0 & 62 \\
\hline Middle $1 / 3$ & 16,784 & 369,245 & 20 & 27 & 39 & 14 & 0 & 53 \\
\hline Top 1/3 & 23,889 & 575,206 & 23 & 26 & 34 & 17 & 0 & 51 \\
\hline \multicolumn{9}{|l|}{ Wealth } \\
\hline Bottom 1/3 & 12,456 & 164,561 & 9 & 24 & 60 & 7 & 0 & 68 \\
\hline Middle $1 / 3$ & 16,666 & 327,034 & 17 & 28 & 39 & 16 & 0 & 55 \\
\hline Top $1 / 3$ & 24,842 & 729,407 & 31 & 28 & 24 & 17 & 0 & 41 \\
\hline \multicolumn{9}{|l|}{ Expenditures } \\
\hline Bottom 1/3 & 9,344 & 373,060 & 21 & 24 & 46 & 9 & 0 & 56 \\
\hline Middle $1 / 3$ & 16,853 & 363,400 & 18 & 25 & 41 & 16 & 0 & 57 \\
\hline Top 1/3 & 34,030 & 585,507 & 32 & 22 & 28 & 18 & 0 & 46 \\
\hline
\end{tabular}


Table 3. Mean Per Capita Household Expenditures and Wealth Among Adults with Median Expenditures Unmarried Adults Ages 65+ Who Collect Either SS or SSDI

\begin{tabular}{|c|c|c|c|c|c|c|c|c|}
\hline & $\begin{array}{c}\text { Total } \\
\text { Expenses }\end{array}$ & $\begin{array}{c}\text { Total } \\
\text { Wealth }\end{array}$ & $\begin{array}{c}\text { Financial } \\
\text { Assets }\end{array}$ & $\begin{array}{l}\text { Housingl } \\
\text { Other }\end{array}$ & $\begin{array}{c}\text { Social } \\
\text { Security } \\
(1)\end{array}$ & $\begin{array}{c}\text { Pensions } \\
\text { IAnnuities } \\
\text { (2) } \\
\end{array}$ & $\begin{array}{l}\text { SSI } \\
(3)\end{array}$ & $\begin{array}{l}\text { Annuitized } \\
\text { Wealth } \\
(1)+(2)+(3) \\
\end{array}$ \\
\hline All & $\$ 18,366$ & $\$ 330,084$ & $14 \%$ & $26 \%$ & $48 \%$ & $10 \%$ & $1 \%$ & $59 \%$ \\
\hline \multicolumn{9}{|l|}{ Age } \\
\hline $65-69$ & 18,693 & 323,827 & 4 & 26 & 59 & 11 & 0 & 70 \\
\hline $70-79$ & 18,849 & 360,077 & 16 & 29 & 45 & 10 & 0 & 55 \\
\hline$>=80$ & 17,407 & 231,031 & 26 & 25 & 40 & 7 & 2 & 49 \\
\hline \multicolumn{9}{|l|}{ Race } \\
\hline Non-Hispanic White & 19,189 & 349,973 & 16 & 28 & 48 & 9 & 0 & 56 \\
\hline Non-Hispanic Black & 16,329 & 132,543 & -7 & 6 & 91 & 10 & 0 & 101 \\
\hline Hispanic & 10,902 & 116,510 & 4 & 11 & 72 & 3 & 9 & 85 \\
\hline \multicolumn{9}{|l|}{ Education } \\
\hline Less than high school & 13,957 & 154,580 & 4 & 24 & 66 & 5 & 0 & 72 \\
\hline GED or high school graduate & 17,321 & 318,205 & 20 & 23 & 47 & 9 & 1 & 57 \\
\hline Some college or more & 25,224 & 567,173 & 22 & 30 & 31 & 17 & 0 & 48 \\
\hline \multicolumn{9}{|l|}{ Sex } \\
\hline Male & 19,338 & 287,072 & 11 & 21 & 53 & 14 & 0 & 67 \\
\hline Female & 18,157 & 350,230 & 15 & 28 & 46 & 10 & 2 & 57 \\
\hline \multicolumn{9}{|l|}{ Self-Reported Health } \\
\hline Excellent / Very Good & 19,886 & 381,174 & 19 & 27 & 45 & 9 & 0 & 53 \\
\hline Good & 17,601 & 318,647 & 18 & 21 & 48 & 11 & 1 & 60 \\
\hline Fair / Poor & 17,595 & 286,521 & 13 & 23 & 49 & 11 & 4 & 65 \\
\hline \multicolumn{9}{|l|}{ Employment Status } \\
\hline Working & 24,129 & 329,875 & 12 & 36 & 48 & 4 & 0 & 52 \\
\hline Not Working & 17,867 & 351,465 & 17 & 24 & 46 & 10 & 2 & 58 \\
\hline \multicolumn{9}{|l|}{ Housing Tenure } \\
\hline Owner / No Mortgage & 18,170 & 455,272 & 22 & 36 & 33 & 9 & 0 & 42 \\
\hline Owner / Mortgage & 25,355 & 418,562 & 12 & 33 & 43 & 12 & 0 & 55 \\
\hline Renter & 15,606 & 126,684 & 7 & 1 & 77 & 9 & 5 & 91 \\
\hline \multicolumn{9}{|l|}{ Urban/Rural } \\
\hline Urban & 19,410 & 389,566 & 22 & 25 & 39 & 14 & 0 & 53 \\
\hline Suburban & 18,638 & 245,166 & 5 & 28 & 56 & 11 & 0 & 67 \\
\hline Rural & 16,751 & 368,593 & 15 & 27 & 50 & 5 & 3 & 58 \\
\hline \multicolumn{9}{|l|}{ Income } \\
\hline Bottom 1/3 & 12,764 & 194,782 & 12 & 29 & 57 & 1 & 1 & 59 \\
\hline Middle 1/3 & 17,582 & 339,808 & 16 & 24 & 47 & 13 & 1 & 61 \\
\hline Top 1/3 & 27,060 & 664,303 & 26 & 27 & 23 & 25 & 0 & 47 \\
\hline \multicolumn{9}{|l|}{ Wealth } \\
\hline Bottom 1/3 & 12,464 & 103,255 & 9 & 13 & 71 & 5 & 3 & 79 \\
\hline Middle 1/3 & 18,019 & 245,904 & 12 & 32 & 46 & 10 & 0 & 56 \\
\hline Top $1 / 3$ & 26,553 & 732,777 & 33 & 30 & 20 & 17 & 0 & 37 \\
\hline \multicolumn{9}{|l|}{ Expenditures } \\
\hline Bottom 1/3 & 8,754 & 223,446 & 12 & 22 & 61 & 4 & 0 & 66 \\
\hline Middle $1 / 3$ & 18,285 & 280,534 & 15 & 26 & 50 & 9 & 0 & 59 \\
\hline Top 1/3 & 38,521 & 567,196 & 24 & 30 & 30 & 15 & 0 & 46 \\
\hline
\end{tabular}


Table 4. Median Per Capita Household Expenditures by Share of Wealth Annuitized Adults Ages 65+ Who Collect Either SS or SSDI

\begin{tabular}{|c|c|c|c|c|c|}
\hline & \multirow[b]{2}{*}{ All } & \multicolumn{4}{|c|}{ Percent of Wealth Annuitized } \\
\hline & & $<25$ & $25-50$ & $50-75$ & $75-100$ \\
\hline \multicolumn{6}{|l|}{ A. Married } \\
\hline Share of Observations & $100 \%$ & $16 \%$ & $30 \%$ & $33 \%$ & $20 \%$ \\
\hline Median Expenditures & $\$ 16,813$ & $\$ 26,790$ & $\$ 17,186$ & $\$ 16,815$ & $\$ 13,266$ \\
\hline \multicolumn{6}{|c|}{ Median Share of Expenditures } \\
\hline Housing & $28 \%$ & $25 \%$ & $25 \%$ & $29 \%$ & $37 \%$ \\
\hline Health Care & $19 \%$ & $14 \%$ & $21 \%$ & $17 \%$ & $18 \%$ \\
\hline Food & $13 \%$ & $9 \%$ & $13 \%$ & $15 \%$ & $13 \%$ \\
\hline Clothing & $3 \%$ & $3 \%$ & $3 \%$ & $3 \%$ & $2 \%$ \\
\hline Transportation & $13 \%$ & $10 \%$ & $12 \%$ & $9 \%$ & $15 \%$ \\
\hline Entertainment & $11 \%$ & $17 \%$ & $14 \%$ & $14 \%$ & $8 \%$ \\
\hline Gifts & $9 \%$ & $11 \%$ & $10 \%$ & $10 \%$ & $5 \%$ \\
\hline Other & $3 \%$ & $11 \%$ & $2 \%$ & $4 \%$ & $3 \%$ \\
\hline Basic & $63 \%$ & $51 \%$ & $62 \%$ & $63 \%$ & $70 \%$ \\
\hline Discretionary & $37 \%$ & $49 \%$ & $38 \%$ & $37 \%$ & $30 \%$ \\
\hline \multicolumn{6}{|l|}{ B. Unmarried } \\
\hline Share of Observations & $100 \%$ & $15 \%$ & $28 \%$ & $25 \%$ & $30 \%$ \\
\hline Median Expenditures & $\$ 18,366$ & $\$ 26,825$ & $\$ 21,303$ & $\$ 18,936$ & $\$ 13,641$ \\
\hline \multicolumn{6}{|c|}{ Median Share of Expenditures } \\
\hline Housing & $41 \%$ & $39 \%$ & $31 \%$ & $42 \%$ & $44 \%$ \\
\hline Health Care & $16 \%$ & $15 \%$ & $16 \%$ & $11 \%$ & $16 \%$ \\
\hline Food & $14 \%$ & $8 \%$ & $12 \%$ & $12 \%$ & $13 \%$ \\
\hline Clothing & $3 \%$ & $4 \%$ & $3 \%$ & $3 \%$ & $5 \%$ \\
\hline Transportation & $10 \%$ & $9 \%$ & $11 \%$ & $12 \%$ & $10 \%$ \\
\hline Entertainment & $7 \%$ & $7 \%$ & $10 \%$ & $8 \%$ & $7 \%$ \\
\hline Gifts & $7 \%$ & $16 \%$ & $13 \%$ & $8 \%$ & $5 \%$ \\
\hline Other & $3 \%$ & $3 \%$ & $5 \%$ & $3 \%$ & $0 \%$ \\
\hline Basic & $73 \%$ & $66 \%$ & $61 \%$ & $68 \%$ & $78 \%$ \\
\hline Discretionary & $27 \%$ & $34 \%$ & $39 \%$ & $32 \%$ & $22 \%$ \\
\hline
\end{tabular}

Note: The universe is unique respondents in the 2001/2003 CAMS ages 65 and older in the 2000/2002 HRS who report receiving either Social Security (SS) or Social Security Disability Insurance (SSDI) in the 2002/2004 HRS. Estimates are based on a sample of 2,053 married and 1,184 unmarried adults. Those with more than 100 percent of wealth annuitized are not shown in this table (23 married and 34 unmarried adults). Basic expenditures include housing, health care, food, and clothing. Discretionary expenditures include transportation, entertainment, gifts, and other consumer durables. The median value is measured as the mean value between the 45 th and 55th percentiles of the distribution. All expenditures are expressed in 2005 dollars.

Source: Authors' estimates from the Health and Retirement Study. 
Table 5. Median Per Capita Household Expenditures by Share of Wealth Annuitized and Income Adults Ages 65+ Who Collect Either SS or SSDI

\begin{tabular}{|c|c|c|c|c|c|}
\hline & & & rcent of & Annuitiz & \\
\hline & All & $<25$ & $25-50$ & $50-75$ & $75-100$ \\
\hline A. Married & & & & & \\
\hline All & $\$ 16,813$ & $\$ 26,790$ & $\$ 17,186$ & $\$ 16,815$ & $\$ 13,266$ \\
\hline Income & & & & & \\
\hline Bottom 1/3 & 12,613 & 17,060 & 12,768 & 12,885 & 10,831 \\
\hline Middle $1 / 3$ & 16,784 & 24,123 & 16,815 & 17,977 & 13,502 \\
\hline Top 1/3 & 23,889 & 32,518 & 24,467 & 22,465 & 20,621 \\
\hline B. Unmarri & & & & & \\
\hline $\begin{array}{l}\text { All } \\
\text { Income }\end{array}$ & $\$ 18,366$ & $\$ 26,825$ & $\$ 21,303$ & $\$ 18,936$ & $\$ 13,641$ \\
\hline Bottom 1/3 & 12,764 & 16,718 & 15,242 & 15,327 & 10,035 \\
\hline Middle $1 / 3$ & 17,582 & 23,199 & 19,205 & 16,815 & 15,130 \\
\hline Top 1/3 & 27,060 & 35,297 & 27,931 & 30,286 & 20,703 \\
\hline
\end{tabular}

Note: The universe is unique respondents in the 2001/2003 CAMS ages 65 and older in the 2000/2002 HRS who report receiving either Social Security (SS) or Social Security Disability Insurance (SSDI) in the 2002/2004 HRS. Estimates are based on a sample of 2,053 married and 1,184 unmarried adults. Those with more than 100 percent of wealth annuitized are not shown in this table ( 23 married and 34 unmarried adults). The median value is measured as the mean value between the 45th and 55th percentiles of the distribution. All expenditures are expressed in 2005 dollars.

Source: Authors' estimates from the Health and Retirement Study. 
Table 6. Median Per Capita Household Expenditures by Share of Wealth from Social Security and Pensions Adults Ages 65+ Who Collect Either SS or SSDI

\begin{tabular}{|c|c|c|c|c|c|c|c|c|c|c|}
\hline & \multirow[b]{2}{*}{ All } & \multicolumn{4}{|c|}{ Percent of Wealth Held in Social Security } & \multirow[b]{2}{*}{ All } & \multicolumn{4}{|c|}{ Percent of Wealth Held in Pensions } \\
\hline & & $<25$ & $25-50$ & $50-75$ & $75-100$ & & 0 & $1-25$ & $25-50$ & $50-100$ \\
\hline \multicolumn{11}{|l|}{ A. Married } \\
\hline Share of Observations & $100 \%$ & $31 \%$ & $40 \%$ & $19 \%$ & $10 \%$ & $100 \%$ & $40 \%$ & $40 \%$ & $15 \%$ & $4 \%$ \\
\hline Median Expenditures & $\$ 16,813$ & $\$ 24,445$ & $\$ 16,371$ & $\$ 14,626$ & $\$ 11,479$ & $\$ 16,813$ & $\$ 15,632$ & $\$ 16,674$ & $\$ 19,302$ & $\$ 19,380$ \\
\hline \multicolumn{11}{|c|}{ Median Share of Expenditures } \\
\hline Basic & $63 \%$ & $53 \%$ & $62 \%$ & $72 \%$ & $61 \%$ & $63 \%$ & $67 \%$ & $65 \%$ & $54 \%$ & $65 \%$ \\
\hline Discretionary & $37 \%$ & $47 \%$ & $38 \%$ & $28 \%$ & $39 \%$ & $37 \%$ & $33 \%$ & $35 \%$ & $46 \%$ & $35 \%$ \\
\hline \multicolumn{11}{|l|}{ B. Unmarried } \\
\hline Share of Observations & $100 \%$ & $27 \%$ & $32 \%$ & $21 \%$ & $19 \%$ & $100 \%$ & $54 \%$ & $30 \%$ & $12 \%$ & $3 \%$ \\
\hline Median Expenditures & $\$ 18,366$ & $\$ 26,574$ & $\$ 19,404$ & $\$ 16,176$ & $\$ 11,567$ & $\$ 18,366$ & $\$ 15,750$ & $\$ 21,961$ & $\$ 22,219$ & $\$ 24,901$ \\
\hline \multicolumn{11}{|c|}{ Median Share of Expenditures } \\
\hline Basic & $73 \%$ & $61 \%$ & $71 \%$ & $79 \%$ & $85 \%$ & $73 \%$ & $77 \%$ & $65 \%$ & $61 \%$ & $68 \%$ \\
\hline Discretionary & $27 \%$ & $39 \%$ & $29 \%$ & $21 \%$ & $15 \%$ & $27 \%$ & $23 \%$ & $35 \%$ & $39 \%$ & $32 \%$ \\
\hline
\end{tabular}

Note: The universe is unique respondents in the 2001/2003 CAMS ages 65 and older in the 2000/2002 HRS who report receiving either Social Security (SS) or Social Security Disability Insurance (SSDI) in the 2002/2004 HRS. Estimates are based on a sample of 2,053 married and 1,184 unmarried adults. Those with more than 100 percent of wealth held in Social Security are not shown in this table (12 married and 18 unmarried adults). Basic expenditures include housing, health care, food, and clothing. Discretionary expenditures include transportation, entertainment, gifts, and other consumer durables. The median value is measured as the mean value between the 45 th and 55 th percentiles of the distribution. All expenditures are expressed in 2005 dollars.

Source: Authors' estimates from the Health and Retirement Study. 
Table 7. Means of Regression Variables Adults Ages 65+ Who Collect Either SS or SSDI

\begin{tabular}{|c|c|c|c|c|c|}
\hline & \multicolumn{2}{|c|}{ Married } & \multicolumn{2}{|c|}{ Unmarried } & \multirow[b]{2}{*}{ Diff. } \\
\hline & Mean & Std. Error & Mean & Std. Error & \\
\hline Total Expenditures & 22,422 & 430 & 27,452 & 1,135 & 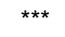 \\
\hline Log of Total Expenditures & 9.762 & 0.015 & 9.812 & 0.027 & \\
\hline Basic Expenditures & 12,873 & 275 & 16,883 & 581 & $\star \star \star *$ \\
\hline Log of Basic Expenditures & 9.218 & 0.015 & 9.386 & 0.025 & $\star \star \star *$ \\
\hline Discretionary Expenditures & 9,549 & 269 & 10,569 & 884 & \\
\hline Log of Discretionary Expenditures & 8.623 & 0.025 & 8.223 & 0.051 & 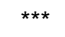 \\
\hline Age & 71.7 & 0.1 & 75.2 & 0.2 & 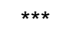 \\
\hline \multicolumn{6}{|l|}{ Race } \\
\hline Non-Hispanic White (dropped) & 0.911 & 0.006 & 0.855 & 0.010 & $\star \star \star$ \\
\hline Non-Hispanic Black & 0.050 & 0.005 & 0.100 & 0.009 & *** \\
\hline Hispanic & 0.039 & 0.004 & 0.045 & 0.006 & \\
\hline \multicolumn{6}{|l|}{ Education } \\
\hline Less than high school & 0.225 & 0.009 & 0.288 & 0.013 & $\star \star \star *$ \\
\hline GED or high school graduate (dropped) & 0.368 & 0.011 & 0.400 & 0.014 & * \\
\hline Some college or more & 0.408 & 0.011 & 0.313 & 0.013 & $\star \star \star *$ \\
\hline \multicolumn{6}{|l|}{ Sex } \\
\hline Male (dropped) & 0.562 & 0.011 & 0.202 & 0.012 & *** \\
\hline Female & 0.438 & 0.011 & 0.798 & 0.012 & $\star \star \star *$ \\
\hline \multicolumn{6}{|l|}{ Self-Reported Health } \\
\hline Excellent / Very Good & 0.454 & 0.011 & 0.395 & 0.014 & $\star \star * *$ \\
\hline Good (dropped) & 0.306 & 0.010 & 0.347 & 0.014 & $\star \star$ \\
\hline Fair / Poor & 0.241 & 0.009 & 0.258 & 0.013 & \\
\hline \multicolumn{6}{|l|}{ Employment Status } \\
\hline Working & 0.100 & 0.007 & 0.094 & 0.008 & \\
\hline Not Working (dropped) & 0.900 & 0.007 & 0.906 & 0.008 & \\
\hline \multicolumn{6}{|l|}{ Housing Tenure } \\
\hline Owner / No Mortgage (dropped) & 0.683 & 0.010 & 0.567 & 0.014 & $\star \star \star *$ \\
\hline Owner / Mortgage & 0.256 & 0.010 & 0.181 & 0.011 & *** \\
\hline Renter & 0.060 & 0.005 & 0.252 & 0.013 & 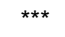 \\
\hline \multicolumn{6}{|l|}{ Urban/Rural } \\
\hline Urban & 0.404 & 0.011 & 0.417 & 0.014 & \\
\hline Suburban (dropped) & 0.291 & 0.010 & 0.299 & 0.013 & \\
\hline Rural & 0.306 & 0.010 & 0.284 & 0.013 & \\
\hline Income & 28,314 & 817 & 26,301 & 938 & \\
\hline Log of Income & 9.956 & 0.015 & 9.855 & 0.021 & $\star \star \star$ \\
\hline Wealth & 455,591 & 11,605 & 393,088 & 13,838 & $\star \star \star$ \\
\hline Log of Wealth & 12.717 & 0.017 & 12.443 & 0.027 & 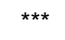 \\
\hline \multicolumn{6}{|l|}{ Marital Status*Sex } \\
\hline Divorced Male & & & 0.064 & 0.007 & \\
\hline Widowed Male & & & 0.110 & 0.009 & \\
\hline Never Married Male & & & 0.028 & 0.005 & \\
\hline Divorced Female & & & 0.152 & 0.010 & \\
\hline Widowed Female (dropped) & & & 0.608 & 0.014 & \\
\hline Never Married Female & & & 0.039 & 0.006 & \\
\hline Spouse Age & 70.3 & 0.2 & & & \\
\hline \multicolumn{6}{|l|}{ Spouse Education } \\
\hline Less than high school & 0.220 & 0.009 & & & \\
\hline GED or high school graduate (dropped) & 0.372 & 0.011 & & & \\
\hline Some college or more & 0.408 & 0.011 & & & \\
\hline \multicolumn{6}{|l|}{ Spouse Self-Reported Health } \\
\hline Excellent / Very Good & 0.455 & 0.011 & & & \\
\hline Good (dropped) & 0.303 & 0.010 & & & \\
\hline Fair / Poor & 0.243 & 0.009 & & & \\
\hline \multicolumn{6}{|l|}{ Spouse Employment Status } \\
\hline Working & 0.133 & 0.008 & & & \\
\hline Not Working (dropped) & 0.867 & 0.008 & & & \\
\hline Year 2003 & 0.123 & 0.007 & 0.174 & 0.011 & $\star \star \star *$ \\
\hline$\%$ Wealth Annuitized & 0.529 & 0.005 & 0.584 & 0.009 & $\star \star \star *$ \\
\hline$\%$ Wealth Held in Social Security & 0.400 & 0.005 & 0.473 & 0.009 & $\star \star *$ \\
\hline$\%$ Wealth Held in Pensions & 0.127 & 0.004 & 0.099 & 0.005 & $\star \star \star *$ \\
\hline
\end{tabular}

Note: The universe is unique respondents in the 2001/2003 CAMS ages 65 and older in the 2000/2002 HRS who report receiving either Social Security (SS) or Social Security Disability Insurance (SSDI) in the 2002/2004 HRS. Estimates are based on a sample of 2,053 married and 1,184 unmarried adults. Basic expenditures include housing, health care, food, and clothing. Discretionary expenditures include transportation, entertainment, gifts, and other consumer durables. All amounts are expressed in 2005 per capita dollars. ${ }^{*} p<.10 ;{ }^{* \star} p<.05$; *** $p<.01$

Source: Authors' estimates from the Health and Retirement Study. 
Table 8. Coefficients from Median Regressions of Per Capita Household Expenditures

Married Adults Ages 65+ Who Collect Either SS or SSDI

\begin{tabular}{|c|c|c|c|c|c|c|}
\hline & $\begin{array}{c}\text { Log of } \\
\text { Expenditures }\end{array}$ & $\begin{array}{c}\text { Log of } \\
\text { Expenditures }\end{array}$ & $\begin{array}{l}\text { Log of Basic } \\
\text { Expenditures }\end{array}$ & $\begin{array}{l}\text { Log of Basic } \\
\text { Expenditures }\end{array}$ & $\begin{array}{c}\text { Log of } \\
\text { Discretionary } \\
\text { Expenditures }\end{array}$ & $\begin{array}{c}\text { Log of } \\
\text { Discretionary } \\
\text { Expenditures }\end{array}$ \\
\hline Age & $0.142 * \star \star$ & $0.141 * \star$ & $0.090 * *$ & 0.108 ** & 0.147 * & 0.087 \\
\hline Age Squared & $-0.001 * \star \star$ & $-0.001 * \star$ & $-0.001 *$ & $-0.001 *$ & -0.001 * & -0.001 \\
\hline \multicolumn{7}{|l|}{ Race } \\
\hline \multicolumn{7}{|l|}{ Non-Hispanic White (dropped) } \\
\hline Non-Hispanic Black & 0.034 & -0.002 & 0.028 & 0.037 & 0.051 & 0.086 \\
\hline Hispanic & $-0.278 * \star *$ & $-0.279 * * \star$ & $-0.232 * \star *$ & $-0.260 * \star \star$ & $-0.214 * *$ & $-0.253 * * *$ \\
\hline \multicolumn{7}{|l|}{ Education } \\
\hline Less than high school & $-0.081 * \star \star$ & -0.047 & -0.052 * & -0.028 & -0.066 & -0.050 \\
\hline \multicolumn{7}{|l|}{ GED or high school graduate (dropped) } \\
\hline Some college or more & $0.071 * \star \star$ & 0.058 * & 0.010 & 0.028 & $0.155 * \star \star$ & $0.161 * \star *$ \\
\hline \multicolumn{7}{|l|}{ Sex } \\
\hline \multicolumn{7}{|l|}{ Male (dropped) } \\
\hline Female & -0.021 & -0.019 & -0.032 & -0.019 & -0.014 & -0.033 \\
\hline \multicolumn{7}{|l|}{ Self-Reported Health } \\
\hline \multicolumn{7}{|l|}{ Good (dropped) } \\
\hline Fair / Poor & 0.025 & 0.014 & 0.064 ** & 0.054 & $-0.133 * \star$ & $-0.163 * \star \star$ \\
\hline \multicolumn{7}{|l|}{ Employment Status } \\
\hline Working & 0.055 * & 0.055 & $0.137 * * *$ & $0.140 * * *$ & -0.030 & -0.008 \\
\hline \multicolumn{7}{|l|}{ Not Working (dropped) } \\
\hline \multicolumn{7}{|l|}{ Housing Tenure } \\
\hline \multicolumn{7}{|l|}{ Owner / No Mortgage (dropped) } \\
\hline Owner / Mortgage & $0.273 * \star \star$ & $0.280 * \star \star$ & $0.484 * \star \star$ & $0.494 * * *$ & 0.070 & 0.046 \\
\hline Renter & $0.217 * * *$ & $0.205 * \star *$ & $0.353 * * *$ & $0.380 * \star *$ & 0.059 & 0.011 \\
\hline \multicolumn{7}{|l|}{ Urban/Rural } \\
\hline Urban & 0.004 & -0.002 & -0.007 & -0.001 & -0.045 & $-0.068 *$ \\
\hline \multicolumn{7}{|l|}{ Suburban (dropped) } \\
\hline Rural & $-0.094 * * *$ & $-0.116 * * *$ & $-0.114 * * *$ & $-0.107 * \star *$ & $-0.110 * *$ & $-0.102 * \star$ \\
\hline Log Income & $0.157 \star \star \star *$ & $0.173 * \star *$ & $0.087 * \star \star$ & $0.070 * \star$ & $0.274 * \star \star$ & $0.270 * \star *$ \\
\hline Log Wealth & $0.244 * * *$ & $0.297 * \star \star$ & $0.171 * * *$ & $0.236 * * *$ & $0.383 * * *$ & $0.440 * * *$ \\
\hline Spouse Age & $0.038 * \star *$ & 0.032 & 0.027 * & 0.018 & 0.017 & 0.024 \\
\hline Spouse Age Squared & $0.000 * *$ & 0.000 & 0.000 & 0.000 & 0.000 & 0.000 \\
\hline \multicolumn{7}{|l|}{ Spouse Education } \\
\hline Less than high school & $-0.111 * \star *$ & $-0.087 * \star$ & $-0.050 *$ & -0.046 & $-0.099 *$ & -0.054 \\
\hline \multicolumn{7}{|l|}{ GED or high school graduate (dropped) } \\
\hline Some college or more & $0.076 * \star \star$ & $0.087 * \star$ & 0.036 & 0.028 & $0.139 * \star *$ & $0.151 * * *$ \\
\hline \multicolumn{7}{|l|}{ Spouse Self-Reported Health } \\
\hline Excellent / Very Good & 0.031 & 0.028 & 0.037 & 0.020 & -0.027 & -0.025 \\
\hline \multicolumn{7}{|l|}{ Good (dropped) } \\
\hline Fair / Poor & 0.045 * & 0.031 & 0.041 & 0.026 & $-0.155 * * \star$ & $-0.159 * \star \star$ \\
\hline Spouse Employment Status & & & & & & \\
\hline Working & $0.078 * \star \star$ & $0.113 * \star$ & $0.141 * \star \star$ & $0.134 * * \star$ & 0.053 & 0.065 \\
\hline Not Working (dropped) & & & & & & \\
\hline Year 2003 & $0.065 * *$ & 0.049 & 0.040 & 0.031 & $0.155 * \star *$ & $0.126 * *$ \\
\hline$\%$ Wealth Annuitized & $-2.331 * \star \star$ & & -0.050 & & $-2.353 * \star$ & \\
\hline \% Wealth Annuitized Squared & $4.421 * \star \star$ & & -0.207 & & 4.558 ** & \\
\hline$\%$ Wealth Annuitized Cubed & $-2.605 * * *$ & & 0.108 & & $-2.809 * *$ & \\
\hline$\%$ Wealth Held in Social Security & & 0.259 & & $1.419 * *$ & & -0.489 \\
\hline \% Wealth Held in Social Security Squared & & -0.234 & & -2.618 ** & & 1.100 \\
\hline \% Wealth Held in Social Security Cubed & & -0.081 & & 1.276 * & & -0.728 \\
\hline$\%$ Wealth Held in Pensions & & $-0.879 * *$ & & -0.460 & & -1.038 ** \\
\hline \% Wealth Held in Pensions Squared & & $3.850 * \star$ & & 0.668 & & $5.976 * * *$ \\
\hline$\%$ Wealth Held in Pensions Cubed & & $-4.287 * * *$ & & -0.006 & & $-7.260 * \star *$ \\
\hline Intercept & -1.529 & -2.549 & 1.356 & 0.003 & -4.717 & -3.890 \\
\hline Pseudo R-Squared & 0.202 & 0.203 & 0.157 & 0.160 & 0.192 & 0.195 \\
\hline
\end{tabular}

Note: The universe is unique respondents in the 2001/2003 CAMS ages 65 and older in the 2000/2002 HRS who report receiving either Social Security (SS) or Social Security Disability Insurance (SSDI) in the 2002/2004 HRS. Estimates are based on a sample of 2,053 married adults. ${ }^{\star} \mathrm{p}<.10 ;{ }^{\star \star} \mathrm{p}<.05 ;{ }^{\star \star \star} \mathrm{p}<.01$ 
Table 9. Coefficients from Median Regressions of Per Capita Household Expenditures

Unmarried Adults Ages 65+ Who Collect Either SS or SSDI

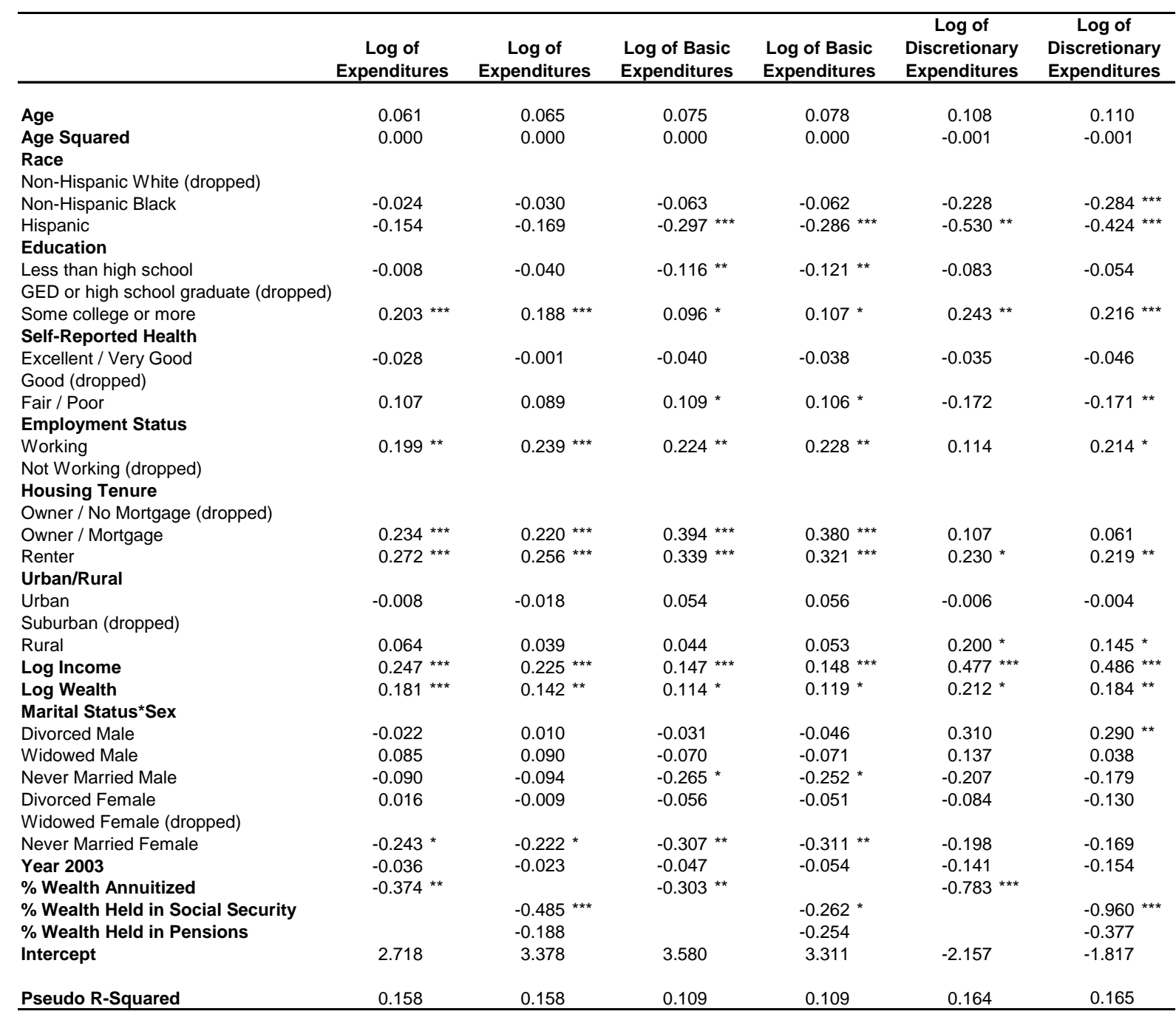


Table 10. Impact of Decreasing the Share of Wealth Annuitized by

10 Percentage Points on Per Capita Household Expenditures

Adults Ages 65+ Who Collect Either SS or SSDI

\begin{tabular}{|c|c|c|c|c|c|c|}
\hline & \multirow{2}{*}{\multicolumn{3}{|c|}{$\frac{\text { Married }}{\text { Social }}$}} & \multicolumn{3}{|c|}{ Unmarried } \\
\hline & & & & & Social & \\
\hline & $\begin{array}{c}\text { Total } \\
\text { Wealth }\end{array}$ & $\begin{array}{c}\text { Security } \\
\text { Wealth }\end{array}$ & $\begin{array}{c}\text { Pension } \\
\text { Wealth }\end{array}$ & $\begin{array}{c}\text { Total } \\
\text { Wealth }\end{array}$ & $\begin{array}{c}\text { Security } \\
\text { Wealth }\end{array}$ & $\begin{array}{c}\text { Pension } \\
\text { Wealth }\end{array}$ \\
\hline \multicolumn{7}{|l|}{ A. Baseline } \\
\hline$\%$ Wealth Annuitized & $55 \%$ & $41 \%$ & $14 \%$ & $59 \%$ & $48 \%$ & $10 \%$ \\
\hline Median Expenditures & $\$ 16,813$ & $\$ 16,813$ & $\$ 16,813$ & $\$ 18,366$ & $\$ 18,366$ & $\$ 18,366$ \\
\hline \multicolumn{7}{|l|}{ B. Simulation } \\
\hline$\%$ Wealth Annuitized & $45 \%$ & $31 \%$ & $4 \%$ & $49 \%$ & $38 \%$ & $0 \%$ \\
\hline$\%$ Change in Total Expenditures & $3 \%$ & $-1 \%$ & $6 \%$ & $4 \%$ & $5 \%$ & $2 \%$ \\
\hline$\%$ Change in Basic Expenditures & $2 \%$ & $-2 \%$ & $3 \%$ & $3 \%$ & $3 \%$ & $3 \%$ \\
\hline$\%$ Change in Discretionary Expenditures & $3 \%$ & $1 \%$ & $7 \%$ & $8 \%$ & $10 \%$ & $4 \%$ \\
\hline
\end{tabular}

Note: The universe is unique respondents in the 2001/2003 CAMS ages 65 and older in the 2000/2002 HRS who report receiving either Social Security (SS) or

Social Security Disability Insurance (SSDI) in the 2002/2004 HRS. Estimates are based on a sample of 2,053 married and 1,184 unmarried adults. Basic

expenditures include housing, health care, food, and clothing. Discretionary expenditures include transportation, entertainment, gifts, and other consumer durables. The median value is measured as the mean value between the 45th and 55th percentiles of the distribution. All expenditures are expressed in 2005 dollars.

Source: Authors' estimates from the Health and Retirement Study. 


\section{Table 11. Impact of Different Annuitized Wealth Scenarios on Per Capita Household Expenditures Adults Ages 65+ Who Collect Either SS or SSDI}

\begin{tabular}{lcc}
\hline & Married & Unmarried \\
\cline { 2 - 3 } $\begin{array}{l}\text { A. Baseline } \\
\text { \% Wealth Annuitized }\end{array}$ & $55 \%$ & $59 \%$ \\
Median Expenditures & $\$ 16,813$ & $\$ 18,366$ \\
& & \\
B. Simulations & & \\
Convert DB to DC Pensions & & $49 \%$ \\
\% Wealth Annuitized & $41 \%$ & $5 \%$ \\
\% Change in Total Expenditures & $2 \%$ & $4 \%$ \\
\% Change in Basic Expenditures & $2 \%$ & $11 \%$ \\
\% Change in Discretionary Expenditures & $3 \%$ & \\
& & $47 \%$ \\
25\% of Social Security is Diverted to PRA & & $4 \%$ \\
\% Wealth Annuitized & $45 \%$ & $3 \%$ \\
\% Change in Total Expenditures & $1 \%$ & $8 \%$ \\
\% Change in Basic Expenditures & $2 \%$ & \\
\% Change in Discretionary Expenditures & $2 \%$ & $35 \%$ \\
& & $8 \%$ \\
50\% of Social Security is Diverted to PRA & & $7 \%$ \\
\% Wealth Annuitized & $34 \%$ & $17 \%$ \\
\% Change in Total Expenditures & $3 \%$ & \\
\% Change in Basic Expenditures & $3 \%$ & $11 \%$ \\
\% Change in Discretionary Expenditures & $4 \%$ & $38 \%$ \\
\hline & & $18 \%$ \\
All of Social Security is Diverted to PRA & $14 \%$ & \\
\% Wealth Annuitized & $21 \%$ & \\
\% Change in Total Expenditures & $22 \%$ & \\
\% Change in Basic Expenditures & & \\
\% Change in Discretionary Expenditures & & \\
\hline
\end{tabular}

Note: The universe is unique respondents in the 2001/2003 CAMS ages 65 and older in the 2000/2002 HRS who report receiving either Social Security (SS) or Social Security Disability Insurance (SSDI) in the 2002/2004 HRS. Estimates are based on a sample of 2,053 married and 1,184 unmarried adults. Basic expenditures include housing, health care, food, and clothing. Discretionary expenditures include transportation, entertainment, gifts, and other consumer durables. The median value is measured as the mean value between the 45th and 55th percentiles of the distribution. All expenditures are expressed in 2005 dollars.

Source: Authors' estimates from the Health and Retirement Study. 
Table A1. Mean Per Capita Household Expenditures and Wealth Among Adults with Median Expenditures Married Adults Ages 65+ Who Collect Either SS or SSDI

\begin{tabular}{|c|c|c|c|c|c|c|c|c|c|}
\hline & $\begin{array}{c}\text { Total } \\
\text { Expenses }\end{array}$ & $\begin{array}{c}\text { Total } \\
\text { Wealth }\end{array}$ & $\begin{array}{c}\text { Financial } \\
\text { Assets }\end{array}$ & $\begin{array}{c}\text { Housing } \\
\text { Equity }\end{array}$ & $\begin{array}{c}\text { Other } \\
\text { Assets }\end{array}$ & $\begin{array}{c}\text { Social } \\
\text { Security } \\
(1) \\
\end{array}$ & $\begin{array}{c}\text { Pensions } \\
\text { IAnnuities } \\
\text { (2) }\end{array}$ & $\begin{array}{l}\text { SSI } \\
(3)\end{array}$ & $\begin{array}{l}\text { Annuitized } \\
\text { Wealth } \\
(1)+(2)+(3) \\
\end{array}$ \\
\hline All & $\$ 16,813$ & $\$ 377,365$ & $\$ 88,888$ & $\$ 62,048$ & $\$ 44,727$ & $\$ 124,741$ & $\$ 56,961$ & $\$ 0$ & $\$ 181,702$ \\
\hline \multicolumn{10}{|l|}{ Age } \\
\hline $65-69$ & 17,412 & 412,137 & 81,380 & 61,964 & 38,973 & 152,326 & 77,494 & 0 & 229,820 \\
\hline $70-79$ & 16,763 & 319,282 & 71,964 & 58,581 & 34,763 & 105,232 & 48,742 & 0 & 153,974 \\
\hline$>=80$ & 14,779 & 391,381 & 139,302 & 99,472 & 53,786 & 78,744 & 20,076 & 0 & 98,820 \\
\hline \multicolumn{10}{|l|}{ Race } \\
\hline Non-Hispanic White & 17,277 & 363,009 & 75,705 & 60,937 & 45,341 & 121,075 & 59,951 & 0 & 181,026 \\
\hline Non-Hispanic Black & 13,936 & 139,188 & 2,697 & 22,600 & 3,130 & 102,687 & 8,073 & 0 & 110,760 \\
\hline Hispanic & 8,704 & 193,989 & 3,250 & 71,868 & 15,802 & 80,577 & 22,493 & 0 & 103,069 \\
\hline \multicolumn{10}{|l|}{ Education } \\
\hline Less than high school & 12,049 & 271,738 & 40,446 & 59,410 & 40,475 & 113,198 & 18,209 & 0 & 131,407 \\
\hline GED or high school graduate & 15,544 & 346,606 & 82,248 & 62,015 & 39,161 & 127,055 & 36,127 & 0 & 163,183 \\
\hline Some college or more & 22,030 & 545,944 & 162,097 & 76,652 & 65,067 & 130,841 & 110,713 & 574 & 242,129 \\
\hline \multicolumn{10}{|l|}{ Sex } \\
\hline Male & 17,211 & 379,120 & 82,807 & 62,042 & 45,273 & 131,177 & 57,822 & 0 & 188,998 \\
\hline Female & 16,316 & 374,031 & 82,477 & 66,140 & 54,447 & 115,961 & 55,007 & 0 & 170,968 \\
\hline \multicolumn{10}{|l|}{ Self-Reported Health } \\
\hline Excellent / Very Good & 19,094 & 423,471 & 104,687 & 61,523 & 58,700 & 132,061 & 66,499 & 0 & 198,560 \\
\hline Good & 16,253 & 342,307 & 70,891 & 58,395 & 40,866 & 114,114 & 58,041 & 0 & 172,155 \\
\hline Fair / Poor & 14,021 & 278,715 & 74,288 & 49,714 & 17,970 & 104,188 & 32,553 & 0 & 136,742 \\
\hline \multicolumn{10}{|l|}{ Employment Status } \\
\hline Working & 19,620 & 308,407 & 36,320 & 60,601 & 23,993 & 154,699 & 32,795 & 0 & 187,494 \\
\hline Not Working & 16,500 & 385,870 & 96,216 & 66,789 & 42,374 & 121,484 & 59,006 & 0 & 180,490 \\
\hline \multicolumn{10}{|l|}{ Housing Tenure } \\
\hline Owner / No Mortgage & 15,092 & 429,440 & 117,148 & 70,176 & 83,543 & 111,795 & 46,779 & 0 & 158,573 \\
\hline Owner / Mortgage & 21,712 & 418,497 & 82,295 & 74,522 & 52,360 & 134,483 & 74,838 & 0 & 209,321 \\
\hline Renter & 16,675 & 161,647 & 13,139 & 0 & 4,675 & 118,661 & 23,029 & 2,143 & 143,832 \\
\hline \multicolumn{10}{|l|}{ Urban/Rural } \\
\hline Urban & 17,973 & 331,651 & 66,600 & 62,309 & 14,839 & 120,450 & 67,088 & 364 & 187,902 \\
\hline Suburban & 17,646 & 411,903 & 148,032 & 57,327 & 35,335 & 120,871 & 50,338 & 0 & 171,209 \\
\hline Rural & 14,607 & 443,163 & 76,515 & 53,526 & 166,213 & 109,125 & 37,784 & 0 & 146,908 \\
\hline \multicolumn{10}{|l|}{ Income } \\
\hline Bottom 1/3 & 12,613 & 236,178 & 36,330 & 51,628 & 21,328 & 112,651 & 14,241 & 0 & 126,892 \\
\hline Middle 1/3 & 16,784 & 369,245 & 88,334 & 67,665 & 45,933 & 122,876 & 44,436 & 0 & 167,313 \\
\hline Top $1 / 3$ & 23,889 & 575,206 & 151,964 & 74,008 & 98,541 & 152,018 & 98,674 & 0 & 250,693 \\
\hline \multicolumn{10}{|l|}{ Wealth } \\
\hline Bottom 1/3 & 12,456 & 164,561 & 15,331 & 35,262 & 5,412 & 95,195 & 13,360 & 0 & 108,556 \\
\hline Middle 1/3 & 16,666 & 327,034 & 57,462 & 58,324 & 33,816 & 124,462 & 52,969 & 0 & 177,431 \\
\hline Top $1 / 3$ & 24,842 & 729,407 & 238,515 & 107,059 & 118,189 & 156,449 & 109,194 & 0 & 265,644 \\
\hline \multicolumn{10}{|l|}{ Expenditures } \\
\hline Bottom 1/3 & 9,344 & 373,060 & 142,517 & 45,519 & 32,839 & 113,858 & 38,015 & 311 & 152,185 \\
\hline Middle 1/3 & 16,853 & 363,400 & 81,632 & 60,202 & 36,782 & 122,097 & 62,687 & 0 & 184,783 \\
\hline Top 1/3 & 34,030 & 585,507 & 223,052 & 85,235 & 42,564 & 132,709 & 101,948 & 0 & 234,657 \\
\hline
\end{tabular}

Source: Authors' estimates from the Health and Retirement Study. 
Table A2. Mean Per Capita Household Expenditures and Wealth Among Adults with Median Expenditures Unmarried Adults Ages 65+ Who Collect Either SS or SSDI

\begin{tabular}{|c|c|c|c|c|c|c|c|c|c|}
\hline & $\begin{array}{c}\text { Total } \\
\text { Expenses }\end{array}$ & $\begin{array}{c}\text { Total } \\
\text { Wealth }\end{array}$ & $\begin{array}{c}\text { Financial } \\
\text { Assets }\end{array}$ & $\begin{array}{c}\text { Housing } \\
\text { Equity }\end{array}$ & $\begin{array}{c}\text { Other } \\
\text { Assets }\end{array}$ & $\begin{array}{c}\begin{array}{c}\text { Social } \\
\text { Security }\end{array} \\
(1) \\
\end{array}$ & $\begin{array}{c}\text { Pensions } \\
\text { IAnnuities } \\
(2) \\
\end{array}$ & $\begin{array}{c}\text { SSI } \\
(3) \\
\end{array}$ & $\begin{array}{c}\text { Annuitized } \\
\text { Wealth } \\
(1)+(2)+(3)\end{array}$ \\
\hline All & $\$ 18,366$ & $\$ 330,084$ & $\$ 72,460$ & $\$ 71,949$ & $\$ 34,254$ & $\$ 105,028$ & $\$ 45,433$ & $\$ 960$ & $\$ 151,421$ \\
\hline \multicolumn{10}{|l|}{ Age } \\
\hline $65-69$ & 18,693 & 323,827 & 36,114 & 82,961 & 21,417 & 133,459 & 49,320 & 556 & 183,335 \\
\hline $70-79$ & 18,849 & 360,077 & 80,670 & 76,915 & 62,215 & 102,324 & 37,848 & 106 & 140,278 \\
\hline$>=80$ & 17,407 & 231,031 & 77,179 & 51,696 & 18,679 & 63,713 & 18,518 & 1,245 & 83,476 \\
\hline \multicolumn{10}{|l|}{ Race } \\
\hline Non-Hispanic White & 19,189 & 349,973 & 73,901 & 79,866 & 39,671 & 115,562 & 40,906 & 67 & 156,535 \\
\hline Non-Hispanic Black & 16,329 & 132,543 & 4,490 & 10,847 & 1,025 & 95,366 & 20,640 & 176 & 116,182 \\
\hline Hispanic & 10,902 & 116,510 & 4,422 & 13,545 & 4,996 & 78,418 & 4,946 & 10,182 & 93,546 \\
\hline \multicolumn{10}{|l|}{ Education } \\
\hline Less than high school & 13,957 & 154,580 & 16,618 & 34,793 & 5,941 & 85,325 & 11,904 & 0 & 97,229 \\
\hline GED or high school graduate & 17,321 & 318,205 & 94,726 & 64,775 & 30,209 & 97,545 & 29,228 & 1,721 & 128,495 \\
\hline Some college or more & 25,224 & 567,173 & 168,363 & 132,815 & 45,149 & 113,832 & 107,014 & 0 & 220,845 \\
\hline \multicolumn{10}{|l|}{ Sex } \\
\hline Male & 19,338 & 287,072 & 70,345 & 52,328 & 9,498 & 102,224 & 52,677 & 0 & 154,901 \\
\hline Female & 18,157 & 350,230 & 77,548 & 78,645 & 40,765 & 106,039 & 46,031 & 1,202 & 153,271 \\
\hline \multicolumn{10}{|l|}{ Self-Reported Health } \\
\hline Excellent / Very Good & 19,886 & 381,174 & 91,164 & 80,570 & 59,306 & 119,108 & 31,026 & 0 & 150,134 \\
\hline Good & 17,601 & 318,647 & 77,339 & 51,376 & 53,762 & 95,820 & 39,442 & 909 & 136,170 \\
\hline Fair / Poor & 17,595 & 286,521 & 73,113 & 60,465 & 3,313 & 106,711 & 37,305 & 5,613 & 149,628 \\
\hline \multicolumn{10}{|l|}{ Employment Status } \\
\hline Working & 24,129 & 329,875 & 65,660 & 109,166 & 31,083 & 106,842 & 17,123 & 0 & 123,966 \\
\hline Not Working & 17,867 & 351,465 & 99,500 & 70,464 & 32,703 & 99,426 & 47,304 & 2,068 & 148,798 \\
\hline \multicolumn{10}{|l|}{ Housing Tenure } \\
\hline Owner / No Mortgage & 18,170 & 455,272 & 135,231 & 112,042 & 53,058 & 100,919 & 54,022 & 0 & 154,941 \\
\hline Owner / Mortgage & 25,355 & 418,562 & 89,306 & 102,543 & 37,586 & 126,416 & 62,711 & 0 & 189,127 \\
\hline Renter & 15,606 & 126,684 & 23,236 & 0 & 1,594 & 78,381 & 19,710 & 3,763 & 101,854 \\
\hline \multicolumn{10}{|l|}{ Urban/Rural } \\
\hline Urban & 19,410 & 389,566 & 102,986 & 90,777 & 14,314 & 110,938 & 70,551 & 0 & 181,489 \\
\hline Suburban & 18,638 & 245,166 & 29,565 & 66,280 & 14,139 & 99,320 & 35,862 & 0 & 135,182 \\
\hline Rural & 16,751 & 368,593 & 109,075 & 53,576 & 95,248 & 92,606 & 15,294 & 2,794 & 110,694 \\
\hline \multicolumn{10}{|l|}{ Income } \\
\hline Bottom 1/3 & 12,764 & 194,782 & 40,544 & 56,344 & 5,573 & 89,920 & 1,345 & 1,056 & 92,321 \\
\hline Middle $1 / 3$ & 17,582 & 339,808 & 87,830 & 64,160 & 38,171 & 115,700 & 31,814 & 2,132 & 149,646 \\
\hline Top 1/3 & 27,060 & 664,303 & 227,036 & 120,171 & 68,402 & 107,753 & 140,940 & 0 & 248,693 \\
\hline \multicolumn{10}{|l|}{ Wealth } \\
\hline Bottom 1/3 & 12,464 & 103,255 & 12,009 & 11,355 & 1,671 & 69,623 & 5,614 & 2,983 & 78,221 \\
\hline Middle $1 / 3$ & 18,019 & 245,904 & 35,283 & 68,320 & 7,162 & 108,907 & 26,232 & 0 & 135,139 \\
\hline Top $1 / 3$ & 26,553 & 732,777 & 272,336 & 151,797 & 61,971 & 121,528 & 125,145 & 0 & 246,674 \\
\hline \multicolumn{10}{|l|}{ Expenditures } \\
\hline Bottom 1/3 & 8,754 & 223,446 & 40,010 & 58,131 & 5,798 & 97,349 & 21,863 & 294 & 119,506 \\
\hline Middle $1 / 3$ & 18,285 & 280,534 & 63,514 & 64,546 & 14,329 & 106,730 & 31,417 & 0 & 138,146 \\
\hline Top 1/3 & 38,521 & 567,196 & 200,683 & 114,995 & 42,971 & 116,132 & 91,612 & 803 & 208,546 \\
\hline
\end{tabular}




\title{
RECENT WORKING PAPERS FROM THE
}

\section{CENTER FOR RETIREMENT RESEARCH AT BOSTON COLLEGE}

\author{
Risk and Reward of International Investing for U.S. Retirement Savers: \\ Historical Evidence \\ Gary Burtless, December 2006
}

State Age Protection Laws and the Age Discrimination in Employment Act Joanna Lahey, November 2006

Age, Women, and Hiring: An Experimental Study Joanna Lahey, November 2006

Optimal Retirement Asset Decumulation Strategies: The Impact of Housing Wealth Anthony Webb, Robert Triest, and Wei Sun, November 2006

The Impact of Aggregate Mortality Rise on Defined Benefit Pension Plans Irena Dushi, Leora Friedberg, and Anthony Webb, November 2006

Health Care Costs, Taxes, and the Retirement Decision: Conceptual Issues and Illustrative Simulations

Rudolph G. Penner and Richard W. Johnson, November 2006

Why Do Boomers Plan to Work So Long?

Gordon B.T. Mermin, Richard W. Johnson, and Dan Murphy, November 2006

Job Tenure and Pension Coverage

Alicia H. Munnell, Kelly Haverstick, and Geoffrey Sanzenbacher, October 2006

Has the Displacement of Older Workers Increased?

Alicia H. Munnell, Steven Sass, Mauricio Soto, and Natalia Zhivan, September 2006

No Place Like Home: Older Adults and their Housing

Timothy Smeeding, Barbara Boyle Torrey, Jonathan Fisher, David S. Johnson, and Joseph Marchand, August 2006

Effects of Public Policies on the Disposition of Lump-Sum Distributions: Rational and Behavioral Influences

William G. Gale and Michael Dworsky, August 2006

All working papers are available on the Center for Retirement Research website (http://www.bc.edu/crr) and can be requested by e-mail (crr@bc.edu) or phone (617-552-1762). 